\title{
Which investors' characteristics are beneficial for initial coin offerings? Evidence from blockchain technology-based firms
}

\author{
Christian Hackober ${ }^{1} \cdot$ Carolin Bock $^{1}$ (])
}

Accepted: 4 January 2021 / Published online: 24 February 2021

(C) The Author(s) 2021

\begin{abstract}
Initial coin offerings have recently become one of the most important funding resources for ventures in the blockchain area. However, often ventures do not rely solely on initial coin offerings as funding source but receive also investments from more established investors prior or during their initial coin offering. In particular, blockchain related ventures have drawn the attention of (corporate) venture capitalists but only less is known on the interplay of these different funding sources and their influence on initial coin offerings as well as on ventures' further development. Based on the signaling theory as well as the resource-based-view our empirical study find that venture capital investors as well as corporate venture capital investors have a significantly positive effect on initial coin offerings. Further, we find that the reputation, the time of treatment as well as the specialization of investors have a positive influence on the initial coin offering. Finally, our results indicate that the positive effect of venture capital investors as well as the specialization of an investor continues to influence blockchain based ventures' success in the mid-term.
\end{abstract}

Keywords Blockchain · ICO · Venture capital · Corporate venture capital · Cryptocurrency $\cdot$ Distributed ledger $\cdot$ Digital tokens

JEL Classification G10 · G20 · G24 · G32 - D82 · L26 · O30

Carolin Bock

bock@ent.tu-darmstadt.de

Christian Hackober

hackober@ent.tu-darmstadt.de

1 Technische Universität Darmstadt/Institute of Entrepreneurship, Hochschulstr. 1,

64289 Darmstadt, Germany 


\section{Introduction}

The introduction of Bitcoin by Nakamoto (2008) paved the way for a completely new technology that has the potential to disrupt entire industries (Friedlmaier et al. 2016; Sultan et al. 2018). Acknowledged as one of the 'Top 10 Emerging Technologies of 2016' by the World Economic Forum (2016), the blockchain technology, which is the underlying concept of Bitcoin, shows that the encrypted and distributed ledger technology (DLT) has the potential to exceed its original application in finance in the future. Driven by steep price increases for Bitcoins in 2017 and the evolution of new application areas for the DLT in logistics and health care services both, research and public interest increased considerably during the last years (Xu et al. 2019).

Moreover, the rise of DLT was accompanied by another remarkable phenomenon. Instead of following typical financing patterns new ventures conduct increasingly Initial Coin Offerings (ICOs), a novel and unique form of blockchain-based funding (Chanson et al. 2018). Whereas the introduction of DLT marks a cutting-edge development from a technological perspective, ICOs mark the same from an entrepreneurial finance perspective. For the very first time, ventures are able to raise large amounts of funding with minimal effort while avoiding compliance and intermediary costs (Kaal and Dell'Erba 2017; Sameeh 2018). This has enabled that in 2018 over 900 early-stage entities have raised over 21.7 billion USD by conducting an ICO and hence surpassing most of other funding types (Malinova and Park 2018). Therefore, the funding of blockchain technology based firms (BTBFs) is an emerging topic in the area of entrepreneurial finance and receives increasing attention from theory and practice (Block et al. 2018; Boreiko and Sahdev 2018; Dusil and Cerny 2018; Fisch 2019; Fisch and Momtaz 2019).

Nevertheless, ICOs are regularly associated with various types of fraud and scam. Hence, from a public and authorities' perspective the rise of ICOs is eyed rather cautiously. The high fraud potential of ICOs is mainly due to the widely absence of regulations and the fact that ICOs "are not subject to specific regulatory requirements and are frequently structured to avoid existing legal and regulatory requirements" (Zetzsche et al. 2017 p.11). In particular, ICOs represent a potential opportunity for people with malicious intentions to conduct fraudulent activities as ICOs are usually not subject to any securities law. Hornuf et al. (2019) identify seven different types of fraud that occur in connection with ICOs (e.g. exit fraud and Ponzi scheme). As a result of the comparable high number of fraud incidences, several countries such as China and South Korea have decided to ban ICOs while others such as the USA established a regulatory framework based on the assessment of tokens and whether they qualify to be treated as securities or not (Tiwari et al. 2020). While a recent study claims that more than $80 \%$ of all ICOs are scam (Dowlat 2018), other studies conclude that the percentage of fraudulent ICOs is much lower and accounts for 2,2\% (Liebau and Scheuffel 2019) to 10\% (Ernst and Young 2018), which represents still a high percentage compared to other investments but seems to be more reliable.

However, ICOs do not substitute other funding mechanisms completely but compete and coexist with them. In particular, venture capital (VC) remains a 
viable source of funding for BTBFs as VC firms aim traditionally to invest in new emerging technologies, hoping for strong future growth (Rosenbusch et al. 2013; Zacharakis et al. 2007). The interest of VC investors in BTBFs is also confirmed by Huang et al. (2019) who show that VCs invest considerably in innovative finance markets. Further, the strong interest is also observable from various news and articles that report the investment of renowned VCs in BTBFs (Kastelein 2017; Kharif and Russo 2018; Russell 2018). As a result from the continued interest of $\mathrm{VC}$, a considerable number of ventures receives funding from more than one source i.e. they combine several sources of funding like VC investments and ICO or see VC investors participate in their ICOs.

This enables ventures to combine advantages of different investor types at different stages of their development. For example, VC and CVC are usually stronger involved in the operational development of the venture, whereas crowdfunding rounds or ICOs provide larger funding amounts on average and enable ventures to gauge the market interest for their products or services. However, ICOs represent at the same time a new type of exit route for VCs as ICOs facilitate the sale of shares.

Due to the novelty of ICOs, little is known so far on the interplay of this type of funding and more established forms like the reception of VC. In particular, existing research in the domain of ICOs examines mainly BTBF-intrinsic factors against the background of ICO success and the level of returns for ICO investors. For example, Benedetti and Kostovetsky (2018) find that ICOs generate average buy-and-hold abnormal returns of $48 \%$ in the first 30 trading days for investors based on a dataset of 4003 planned and executed ICOs. On the other hand, Momtaz (2018) present evidence that the loyalty of CEOs facilitates the attraction of investors and Rhue (2018) demonstrates that the code quality as well as website characteristics and the degree of social media presence influence the ICO success. Furthermore, Howell et al. (2018) find that ICO success is associated with disclosure and credible commitment of the founder team while An et al. (2019) conclude that the business and technical background of founders as well as the size of their social network influences the success of respective ICOs. Thus, Fisch and Momtaz (2019) are one of the very first who examine the influence of VC investors in the context of ICOs and demonstrate their beneficial impact. However, as they focus mainly on the question whether VCs are able to select superior BTBFs or if BTBFs benefit rather from the investors' treatment, they do not provide a detailed view on the characteristics and interrelation of investors which might impact the success of ICOs. Hence, this work is one of the first to shed light on the interplay of different investor types and their specific characteristics in the context of blockchain and their subsequent impact on BTBFs' success. Thereby, we draw on the general research in the area of financing entrepreneurial ventures as well as on the signaling theory (Spence 1973) in order to provide additional insights to this question.

The remaining paper is structured as follows. First, we shed light on the general development and characteristics of ICOs. Second, we develop our research hypotheses, followed by the introduction of our data set and the used econometrical method. Third, we conclude by presenting our results and their implications and discuss potential limitations of our study. 


\section{Evolving of ICOs as financing instrument}

Simultaneously to the introduction of cryptocurrencies, as a new means to clear payments, the idea arose to use cryptocurrencies and blockchain technology to conduct ICOs (Adhami et al. 2018). Economically, "ICOs can be defined as open calls for funding promoted by organizations, companies, and entrepreneurs to raise money through cryptocurrencies, in exchange for a 'token' that can be sold on the internet or used in the future to obtain products or services and, at times, profits" (Adhami et al. 2018, p. 65) or in other words they are "an unregulated form of a crowdsale to raise funds through a blockchain by selling venture-related tokens or coins in exchange for legal tender or cryptocurrencies" (Amsden and Schweizer 2018, p. 7). That means, in an ICO, ventures offer a stock of specialized crypto tokens for sale with the promise that those tokens will operate as the only medium of exchange when accessing the venture's future product (Catalini and Gans 2018; Li and Mann 2018). From a technical perspective, there are several ways how to design an ICO (using an existing blockchain vs. creating a new blockchain) which are not addressed in this paper as we categorize all ICOs as a novel and unique form of blockchain enabled financing (Chanson et al. 2018). For a more technical detailed discussion of ICOs and blockchain please refer to Amsden and Schweizer (2018) or Chen (2018).

While ICOs have become the dominating form of financing mechanism in the blockchain area they are assumed to disrupt well-established industries that rely on traditional funding sources as well (Chanson et al. 2018; Gomber et al. 2017). The meteoric rise of ICOs is also observable when looking at numbers of ventures that have conducted an ICO as well as at the amount of money that has been raised in these. Although 2019 has represented a slowdown compared to 2018 when more than 14 billion USD were raised within more than 2430 ICOs (Fromberger and Haffke 2019), the volume and value of ICOs has remained considerably high. While the general economic slowdown in 2019 might has translated into a lower number of ICOs, Liebau and Scheuffel (2019) contemplate that a considerable number of past ICOs were scams and hence lead to a current retrenchment of investors. Following this argument, one needs to consider that poor economic performance is often regarded as scam which is in fact misleading. Rather it can be assumed that ventures that conduct an ICO are disproportionately at risk to fail due to their nascent development stage (Liebau and Scheuffel 2019) and their foreignness to the institutional environment (Zaheer 1995). However, it cannot be ruled out that disappointing token price developments of past ICOs have dampened investor's enthusiasm in 2019 and led to a decline of ICOs as indicated by Shifflett and Jones (2018). Furthermore, Blaseg (2018) find evidence that investors have learned to identify 'red flags' earlier and hence many ICOs fail to receive funding. Generally, ICO markets may have returned to a normal level of activity after a phase of exaggeration which was fueled by the investors' hope for high returns in 2017 and early 2018.

Although blockchain and ICO are rather nascent technologies, research interest increased considerably in recent times (Bakos and Halaburda 2018; Xu et al. 2019). Generally, research in this area can be classified into two separate streams. 
First, the general application of blockchain and its impact on various industries has been examined by several researchers. Several analyses were conducted to explore the importance of blockchain for different industries and whether the blockchain technology can disrupt them (Sultan et al. 2018; Varma 2019). In particular, the importance of the blockchain development for the financial industry received extensive attention and has identified that its application may transform traditional trading methods and practice in the financial industry (Ashta and Biot-Paquerot 2018; Chen et al. 2017; Kim and Sarin 2018). Furthermore, Gomber et al. (2018) see that the introduction of blockchain will particularly impact four 'financial' areas: operations management, payments, deposit services, and lending, whereas Dierksmeier and Seele (2018) discuss impacts on business ethics that may arise from the introduction of blockchain.

The second research stream in this area, which is even more relevant for our research setting, concerns ICOs, their application and impact. Howell et al. (2018) discuss in their paper if ICOs are an alternative to more traditional funding sources for new ventures, such as angel investors, VC investors, initial public offerings (IPOs), or pre-sale crowdfunding platforms like Kickstarter. Catalini and Gans (2018) examine under which conditions entrepreneurs may prefer ICOs vs. competitive VC markets. Thereby, they derive respective conditions and characterize the optimal token supply schedule by relying on a game theory approach. Furthermore, there exist several studies that explore success determinants of ICOs (Adhami et al. 2018; Ante et al. 2018). For example Fisch (2019) examines the technical capabilities of ventures and how they impact the amount of funding in ICOs including the quality of their source code and the quality of their disclosed whitepaper. However, the sole use of ICOs as source of financing is rather seldom and, in most cases, ICOs are supplemented by angel investments or VC. Surprisingly, this issue has raised only limited attention in existing literature. Lin and Nestarcova (2019) discuss if blockchain businesses represent new investment opportunities for VC investors and which risks this brings on the table. To our knowledge, only Fisch and Momtaz (2019) examine the role of VC in ICOs. In particular, they explore the signaling role of VC in ICOs and whether VC backed BTBFs outperform their peers. However, while examining the role of $\mathrm{VC}$ investors in ICOs, they do not consider individual characteristics of VC investors and their investment style in detail. Thus, by investigating the influence of investors' characteristics like their reputation or their level of sector specialization which have proven to influence the success of respective portfolio companies (Bertoni et al. 2019; Gompers et al. 2009; Hochberg et al. 2015; Lee et al. 2011; Shu et al. 2011), we enhance the understanding on the interrelation between investors, ICOs and the mid-term success of BTBFs. More precisely, our research provides a more nuanced view on the beneficial influence of $\mathrm{VC}$ investors in ICOs and the development of BTBFs.

\section{Background of ICOs and interplay with other funding sources}

Securing of funding and liquidity represents one of the largest challenges for new ventures (Achleitner et al. 2011; Breuer and Pinkwart 2018; Fisch and Momtaz 2019). Traditionally, new ventures try to access external capital like angel, seed or 
venture capital in order to receive capital for their future growth and development. However, by doing this, entrepreneurs have often faced severe frictions (An et al. 2019). ICOs offer a way to reduce these kinds of frictions or even to overcome them completely. Existing literature has identified four primary reasons that make ICOs attractive and successful (Amsden and Schweizer 2018) in particular in comparison to traditional funding mechanisms.

First, ICOs help to overcome moral hazard and reduce information asymmetries (Momtaz 2018, 2019) by relying on immutable, non-negotiable governance terms when using blockchain technology (Howell et al. 2018). Respective governance terms are available to investors ex ante to their investment decision and cannot be changed ex post, signaling a strong commitment of the founding team on venture governance. Subsequently, the founding team has almost no possibility to benefit themselves on the expense of other investors and hence a potential moral hazard is reduced considerably (An et al. 2019). However, Momtaz (2020) argues that signaling needs to be viewed with caution in the context of ICOs. Entrepreneurs might be incentivized to bias signals of venture quality in ICOs to their advantage due to the absence of regulatory institutions that verify signals neither ex ante nor ex post. This phenomenon might be reinforced by the desire of entrepreneurs to compete successfully with other funding projects which are also incentivized to send biased signals. The absence of regulatory institutions is thereby also one of the biggest advantages of ICOs as this results in lower entry hurdles and costs. One possibility to reduce the incentives for such bias might be to list tokens on exchanges quite immediately after the ICO and thus to reflect the real value more instantly including the threat of declining token prices by punishing biased signals (Momtaz 2020).

Second, by excluding most intermediary cost, ICOs possess a higher cost efficiency than other forms of financing (Amsden and Schweizer 2018). Basically, the entire generated value accrues to the token holders, i.e. investors, instead of to the intermediaries and sponsors in traditional networks.

Third, compared to other entrepreneurial financing options, ICOs offer the possibility to attract a wide range of investors. Whereas, traditional early stage financing options like venture capital are restricted to very few investors, ICOs 'democratize' the investing process as they permit "a broader range of individuals, who may be excluded from investing in traditional financing instruments, to invest in high-risk, high-return venture projects" (An et al. 2019, p. 34). In fact ICOs show a high degree of similarity with IPOs (Benedetti and Kostovetsky 2018) as IPOs sell a share of ownership from the company while an ICO sells a share from the project (Chohan 2017). Thus, permitting access to the investment process for a broad range of individuals can also be beneficial for the future venture's development as the investor universe can comprise future customers (An et al. 2019) leading to higher product awareness and enabling ventures to gauge future market demand (Chod and Lyandres 2018; Momtaz 2018).

Lastly, ventures and investors in ICOs benefit from rapid liquidity if the token gets listed on an exchange platform (Amsden and Schweizer 2018). In contrast to traditional shareholdings of investors in ventures which are of rather captive nature, tokens can be sold almost immediately by investors without harming the project itself after the ICO. However, the listing of tokens is often rather costly for issuers 
as exchanges charges up to several million USD as listing fee (Boreiko and Vidusso 2019; Howell et al. 2020). Hence, a considerable number of tokens is not listed and investors suffer from illiquid markets and a lack of transparency regarding the real value of tokens.

Nevertheless, certain disadvantages can arise for BTBFs when using ICOs as their (solely) source of financing. As already mentioned, ICOs share a couple of similarities with IPOs or crowdfunding campaigns (the average amount of capital raised within ICOs make a comparison with IPOs more suitable whereas given the usual development stage of the venture, a comparison with crowdfunding campaigns seems to be more appropriate). In general, ICOs do not offer any support for ventures beside contributing financial capital which represents a huge difference to other types of early stage investors. Early stage investors provide usually non-financial support to their portfolio companies which comprises legal and management services among others as well as the provision of strategic advice. Existing research has identified non-financial support as a success-critical factor on the growth path of young ventures (Amornsiripanitch et al. 2015; Hellmann 2002; Sapienza 1992). Of course, this cannot be provided by ICOs or crowdfunding campaigns, as the larger investor universe limits the influence of individual investors and the anonymity of investors impede strong personal relationships. However, BTBFs receive also continued interest from more established early stage capital providers (Kastelein 2017; Kharif and Russo 2018; Russell 2018). As a consequence, these ventures are able to raise funding from several sources which enables them to combine different investor characteristics and advantages. Specifically, we observe that a considerable number of BTBFs receive angel or seed capital, followed by VC investments before finally conducting an ICO. This observation is in line with Kaplan and Lerner (2010) who estimate that roughly $60 \%$ of all IPOs are VC backed which can be transferred to our context as IPOs share several similarities with ICOs. We assume that the nonfinancial support of VCs increases notably the success rate of ventures, whereas subsequent ICO events provide sufficient levels of capital for their mid- to long-term growth path. At the same time, ICO events represent additional attractive exit routes for VCs that have been invested prior to them.

\section{Hypothesis development}

Generally, the investment in young ventures is characterized by a high level of uncertainty and information asymmetries (Hellmann and Puri 2002). This holds also in the case of BTBFs and in particular when they conduct an ICO since the quality of a venture is often not directly observable by potential investors (Stuart et al. 1999). Especially, small and private investors who participate often in ICOs are facing large challenges when determining the true quality of a venture and subsequently deciding to invest (Ahlers et al. 2015). Hence, ventures need to send signals to attract potential investors and to convince them from their quality and future development perspective (Bocks et al. 2019). Due to the absence of regulatory requirements, investors need to rely entirely on signals that are sent on a voluntary basis by the venture which increases the risk for fraud and biased signals. However, 
regulatory obligations come usually at the cost of increasing bureaucracy and hence might hamper particularly very nascent ventures to conduct an ICO while also being difficult to enforce due to national borders of regulatory power (Tiwari et al. 2020). Thus, regulatory provisions might be of limited applicability. An alternative option for ventures to create trust of investors might be represented by the option to organize personal investor meetings or to hold live FAQ sessions on Youtube channels or to strive for an early exchange listing (Momtaz 2020).

From a theoretical perspective, this draws on the signaling theory which was initially introduced by the seminal work of Spence (1973) and which is concerned with the reduction of information asymmetries in investor-investee relationships. Past research has already identified the relevance of signaling technical capabilities (Fisch 2019), founder team characteristics (An et al. 2019) and commitment of founders to invest (Fisch 2019; Vismara 2016) in ICOs as success critical.

Furthermore, existing literature in the VC area has stressed which factors act as signal for VCs to invest. However, we argue that the VC investment itself represents a signal to future investors which is in line with Davila et al. (2003) and Baum and Silverman (2004) who find that the existence of VC investors represents an indicator for a certain level of quality of the venture. Moreover, Momtaz (2020) proposes that an 'external certification' which can be achieved through the due diligence of reputable auditors or VC backing might help to overcome the dilemma that emerges from the bias of voluntary signals sent by ventures.

Basically, we assume that the positive signal of existing VC investors is grounded on two distinct research streams that lead to superior performance and abnormal returns. First, VCs are supposed to select more promising ventures (selection effect) (Baum and Silverman 2004; Bertoni et al. 2011) and second to support them by providing complementary assets and services (treatment effect) (Fisch and Momtaz 2019; Jackson et al. 2012).

However, existing research in the VC domain remains ambiguous whether VCs are really able to select superior ventures (Baum and Silverman 2004). Several research concludes that VCs are not always able to select superior ventures or if they are able to identify them, VCs may not be able to invest in them (Bertoni et al. 2011; Colombo and Grilli 2005, 2010) as the ventures' superior nature enables them to self-select their sources of capital.

On the other side, several papers conclude that VCs are able to select superior ventures and to add substantial value during the holding period leading in combination to significant higher returns as VCs devote significant management resources to identify and understand promising ventures before investing in them (Davila et al. 2003). Subsequently, other research finds VCs are usually able to identify ventures that yield high future growth potentials and promise superior future returns (Baum and Silverman 2004; Bertoni et al. 2011; Chemmanur et al. 2011; Rosenbusch et al. 2013) by growing a mostly scalable business model.

Due to their investment model, VCs do not rely completely on public information when they make investment decisions but can fall back on valuable information which they obtain from their networks (Alexy et al. 2012). In particular, we argue that this leads to an information advantage and hence that the investment of respective VCs represents a positive signal to other investors during ICOs which is 
in line with Fisch and Momtaz (2019) who find that VC backed BTBFs outperform substantially their peers. Furthermore, given the superior performance of VC backed ventures, the existence of a VC investor which is invested prior to the ICO can act under such circumstances as a signal to future investors by indicating a certain quality of the venture (Baum and Silverman 2004; Davila et al. 2003). This aspect is in particular important in the context of ICOs as publicly available information around ICOs is rather restricted and the fraud potential is considerably high (Fisch 2019).

However, besides making supposedly better investment decisions, VCs support their portfolio companies by providing a broad range of value-adding services and hence facilitate their growth during the holding period (Jackson et al. 2012; Tykvová 2018). This positive effect relies thereby majorly on the resource-based view, as VCs provide their portfolio firms resources they would otherwise lack (Baum and Silverman 2004; Fisch and Momtaz 2019; Rosenbusch et al. 2013). First, a VC investment is generally associated with an infusion of management expertise (Baum and Silverman 2004) which is crucial as ventures usually do not have an experienced management team due to their novelty. VCs increase the level of professionalization and provide multifold services to their venture through their influence. These services include among others HR, accounting and marketing services (Hellmann and Puri 2002). However, VCs help also to establish governance procedures and organizational set-ups of their portfolio companies by providing coaching and access to their network (Bertoni and Tykvová 2012; Hellmann and Puri 2002). Furthermore, VCs monitor their portfolio companies directly by taking board seats and incorporating respective legal clauses in formal contracts which reduces potential fraud risks and increases the feedback quality. Cumming and Johan (2007) argue thereby that both formal contracts and informal governance mechanisms are beneficial for the venture's development. Thus, the VC existence prior or during the ICO i.e. the respective signal reduces information asymmetry between investees and potential investors.

Hence, we derive the following hypothesis:

\section{H1: VC backing increases ICO and mid-term success.}

Based on the assumption that VC backing is generally beneficial for ventures, the investment time, i.e. treatment time of the $\mathrm{VC}$, should influence the ventures' performance. Existing research provides certain evidence that ventures that are younger when they receive their first round of investment have a significantly higher chance to become a high flyer than their older counterparts (Streletzki and Schulte 2013). In particular, we see three effects that might play a role when assessing whether the investment timing of VCs influences the success probability of BTBFs.

First, existing research provides certain evidence that VCs are able to select superior ventures, i.e. picking winners (Megginson and Weiss 1991; Stuart et al. 1999). However, this superior selection is not only limited to investing in better ventures but includes that VCs are invested earlier in them. Subsequently, Baum and Silverman (2004) provide evidence that VCs are able to identify and preinvest in those ventures that are particularly likely to exhibit superior future performance.

Second, investing in very early stages extends the potential treatment period of VCs and hence the VCs' influence on the ventures' development which should 
raise the probability to close existing resource lacks and contribute to a successful development of the venture. This is in line with Grilli and Murtinu (2015) who present that very young ventures benefit more from the treatment effect provided by VCs than more mature ventures. In particular, they find that the treatment effect on sales growth is quite stronger for ventures that are younger at the time of the first VC investment. In addition to this, Cumming and Johan (2010) find that the value added, provided by VCs, is linked to the investment duration as longer investment durations result in higher value add.

Third, the lack of complementary resources is particularly large shortly after foundation and hence the potential for VCs is larger. Particularly, prior research has found that $\mathrm{VC}$ is able to contribute value by providing complementary resources particularly in very early stages of the venture's life (Bertoni et al. 2011; Sapienza et al. 1996). The reason for this effect is that very early stage ventures are on average in greater need of coaching (Fisch and Momtaz 2019) as they tend to exhibit a greater lack of resources. In addition to this, the VC investment implies of course also a certification for the respective venture which represents a positive signal to potential future investors.

These arguments result in the following hypothesis:

H2: Earlier VC backing increases ICO and mid-term success.

Assuming that $\mathrm{VC}$ investors that are invested in a venture prior to a potential ICO represent a positive signal to follow-on investors during ICOs, the question remains whether investors' characteristics have a moderating role on the signal that is sent to other market participants. However, relevant investor characteristics need to be observable by other market participants in order to have a signaling function. Among other characteristics, the reputation of an investor can have a signaling function as the reputation is rather public and can easily be obtained by the respective recipients. This is important as producing and receiving a signal must outweigh the cost of its production (Connelly et al. 2010).

Generally, the reputation of a firm is defined as an intangible asset that is based on public recognition of the quality of a firm's activities and outputs (Lee et al. 2011; Rindova et al. 2005; Shapiro 1983). In the case of VC investors, the reputation is based on VC firm's prior experience and performance which is seen to be economically important (Achleitner et al. 2018) as well as on VC's network capabilities (Alexy et al. 2012) and the level of direct assistance that is provided to portfolio firms (Hsu 2004). Furthermore, VCs with a higher reputation have usually been able to realize higher returns in the past which gives some indication that they will do so in the future as well (Phalippou 2010). Subsequently, a venture's partnership with a reputable VC signals both the present and future quality of the respective firm (Gulati and Higgins 2003). This is thereby in line with past research of Stuart et al. (1999) who have found that firms which have well-known equity partners and prominent alliance partners perform better.

Further, past research has shown in particular the beneficial impact of prestigious investors in the context of IPOs (Hamza and Kooli 2011; Megginson and Weiss 1991; Shu et al. 2011) as well as in the case of equity crowdfunding (Vismara 2016), which is highly relevant in our context as both funding events show remarkable 
similarities to ICOs. The superior performance of ventures that are backed by more reputable VC investors relies thereby on two separate levers. First, more reputable VCs seem to be able to select better ventures (selection effect) (Hamza and Kooli 2011; Krishnan et al. 2011; Nahata 2008) compared to other investors. Second, more reputable investors add substantive value to ventures during their holding period (Krishnan et al. 2011; Lee et al. 2011). However, as the concept of investor reputation can hardly be quantified, research considers commonly the share of investments exited via an IPO of a specific investors as a proxy (Bottazzi et al. 2008; Jackson et al. 2012; Nahata 2008).

Particularly, we argue that the reputation of the VC investor enforces the signal to follow-on investors during subsequent ICOs based on the two previous identified levers. Thereby, we assume that more reputable VCs facilitate the ICO process and enable better outcomes. Interestingly, higher reputations itself initiate a self-enforcing mechanism as more reputable investors attract ventures of higher quality which seek funding and hence retain a higher probability of superior future returns which increases again the VC's reputation. Thus, the backing of a venture by a highly reputable VC investor represents a certification (Megginson and Weiss 1991) and sends a quality signal to other market participants during the ICO, i.e. the signal indicates a lucrative investment opportunity. As a result, we hypothesize the following:

H3: Backing by more reputable VCs increases ICO and mid-term success.

While historically VC investors focused primarily on certain investment stages, recently the specialization on certain industries has become more popular (Hagendorff et al. 2009; Siddiqui et al. 2016). However, this aspect raises the question whether industry-specialized VC investors are able to outperform generalists and whether existing findings hold in the blockchain context. Existing research shows ambiguous results whether industry-specialized investors outperform generalists (Le Nadant et al. 2018). While Hagendorff et al. (2009) find no statistically significant relationship between industry specialization and portfolio company success as measured by the number of IPOs, Matusik and Fitza (2012) provide evidence that the relationship between portfolio company success and VC firm industry-specialization follow a U-shape with VCs having a moderate level of diversification showing the lowest performance. These findings are further supported by Gompers et al. (2009, p. 843) who find that "the performance of specialized firms appears to be better in general" after reviewing a global dataset of 11,297 portfolio companies. However, it is important to note that the knowledge i.e. the specialization of a VC firm relies majorly on past experience in the industry of the respective portfolio firm. Subsequently, Le Nadant et al. (2018) provide empirical evidence that investors with experience in the industry of their portfolio companies are more beneficial to their portfolio companies.

Generally, specialized (VC) investors are presumed to have a better performance due to two major effects. First, specialized VCs are able to select more promising ventures as their expert knowledge enables them to assess market potentials and business quality more reliably (Gompers et al. 2009). Second, specialized VCs are presumed to provide appropriate support due to their experience and market knowledge enabling a better development of the venture (Hagendorff et al. 2009). 
Summarizing both effects, generalist VC firms are assumed to be worse at allocating capital compared to specialized VC firms (Rajan et al. 2000; Scharfstein and Stein 2000).

As BTBFs represent a rather young industry which is highly complex due to the novelty of the technology and the strong usage of highly dispersed business models, we assume that a deep industry understanding of VCs is beneficial for respective portfolio companies and the findings from the more general $\mathrm{VC}$ research can be transferred to the blockchain context without any limitations. Furthermore, we assume that deep industry knowledge is represented by a stronger specialization of the respective VC. For BTBFs, we assume that the superior selection capabilities as well as the superior treatment of blockchain specialized investors should influence the ICO outcome of BTBFs.

H4: Backing by blockchain-specialized investors increases ICO and mid-term success.

Past research in the field of entrepreneurial finance has widely stressed the benefits of corporate venture capital (CVC) investors for portfolio firms (Galloway et al. 2017; Ivanov and Xie 2010). For example Park and Steensma (2012) show that CVC investors can contribute to the portfolio companies' development by providing valuable managerial resources. Furthermore, Chemmanur et al. (2014) find that CVCs can nurture innovation in portfolio firms and hence lead to a superior development. Unlike usual VC investors, which pursue predominantly financial objectives, most CVC investors combine strategic and financial goals (Block et al. 2018; Rossi et al. 2017) in order to contribute to the overall parent companies' strategy. In particular, they offer usually access to non-financial assets of the parent company including expertise, infrastructure for product development, manufacturing, legal, sales, distribution and customer service activities among others (Park and Steensma 2012) which can facilitate the ventures' development and which differentiates CVCs from pure financial investors. Especially in the very beginning of a venture's lifetime this support can help to commercialize its products or services (Paik and Woo 2017). Furthermore, renowned CVCs can reduce the widespread uncertainty for new technologies that are introduced by ventures. By backing these ventures, CVCs create a technology endorsement effect as they signal markets that they are convinced by a technology which is a strong argument for other market participants to apply these products (Paik and Woo 2017). CVC investments represent subsequently a certification for the ventures' products and services. Although, BTBFs are a rather new phenomenon, we see a considerable number of CVC investors that are invested in them. As BTBFs are often very nascent, in particular before they conduct potentially an ICO, we assume that the processes and influences that impact BTBFs are similar to the processes and influences that impact the more general group of ventures and hence that BTBFs can benefit from CVC support and access to complementary assets. Subsequently, we presume that the support as well as the certification effect influence the ICO, if the CVC is invested previous to this funding event. Hence, we follow:

H5: The receipt of a CVC investment increases ICO and mid-term success. 


\section{Research design}

\subsection{Sample}

We test our hypotheses using a comprehensive sample of BTBFs. We focus on BTBFs as these ventures are most probably conducting ICOs due to their technological proximity. In order to identify relevant ventures, we conducted the Blockchain Startup Tracker provided by Outlier Ventures, a VC investor focused on BTBFs, which was founded in 2014 and which tracks developments around BTBFs since 2016. As per 18th April 2019, we were able to retrieve a list of 1731 BTBFs from Outlier Ventures which serves as basis for our research. In order to ensure the comprehensiveness of our dataset, we crosschecked the number of identified ventures with other sources and research (Fisch 2019; Fisch and Momtaz 2019) but cannot find any substantial misses. We doublechecked the blockchain relatedness of each venture by accessing the venture's website and evaluating respective business descriptions as well as consulting third-party descriptions and, if available, disclosed whitepapers. In addition to this, we performed an extensive web research whether a venture was still active as per 18th April 2019 or not. In particular, we assumed that if a venture's website was no longer available at that date that the respective venture has stopped operating.

Furthermore, we merged the list of ventures with Crunchbase data for getting details on investors and funding rounds. Crunchbase is a free online database which was founded in 2005 and which provides information about technology companies, investors, and funding details majorly focused on the US market. Though the Crunchbase database is comparably young, it becomes increasingly popular in VC research (Croce et al. 2016; Homburg et al. 2013; Schlichte et al. 2019; Werth and Boeert 2013).

Unfortunately, the information on ICOs and BTBFs is not complete for all entries, which is a common issue in ICO and entrepreneurial finance research (Fisch 2019; Kaplan and Lerner 2016). In order to mitigate this issue, we hand-collected missing data to the extent possible from various additional data sources, e.g. ICObench, CoinGecko, and ICO Rating. After excluding incomplete entries, our sample consists of 649 BTBFs that have conducted an ICO and out of which 182 received at least one round of VC financing. Moreover, 17 out of these 649 BTBFs received at least one round of CVC funding.

Data for GDP growth in respective countries were taken from World Bank's World Development Indicators database. Furthermore, data on historic bitcoin prices was gathered from Coinmarketcap, which is one of the most established sources in ICO research (Fisch 2019; Fisch and Momtaz 2019; Lyandres et al. 2018). Finally, we retrieved the amount of annually raised VC from KPMG (2019).

\subsection{Variables}

\subsubsection{Dependent variables}

In order to investigate the hypotheses just outlined we use two different dependent variables. First, we follow existing research and incorporate the amount of funding 
raised during the ICO as success measurement (Ln_amount_ICO) for the respective venture (Fisch 2019; Fisch and Momtaz 2019; Momtaz 2018). Based on the assumption that ventures strive to achieve the highest possible amount of funding during their ICO, the received amount of funding represents a direct success indicator as it enables future growth options and indicates the venture's value for existing shareholders. Furthermore, as success-related data is rather scarce in the area of entrepreneurial finance, the amount of ICO funding represents one of very few opportunities to get an indicator on an objectively confirmed venture valuation similar to more general financing events like funding rounds, IPOs, or crowdfunding campaigns. The amount of funding during ICOs is thereby directly linked to the future development of the BTBF as the received proceeds enable BTBFs to grow their business and invest in required resources. As the amount of funding received during ICO events is highly skewed, we apply the natural logarithm of the respective amount.

Second, we apply a binary variable Survived which equals one if the respective BTBF is still operating as per 18th April 2019 and zero otherwise. Applying this second dependent variable as success measurement helps to shed light on BTBF's sustainability as well as on their mid-term development. Particularly, this approach allows us to differentiate between factors that impact the short-term success as well as the mid-term success of BTBFs. Further, the application of two variables measuring the success of the BTBF adds robustness to the results.

\subsubsection{Independent and control variables}

In addition to the dependent variables used, the independent and the control variables are summarized in Table 1. In order to answer the question whether financial investors, i.e. VC investors, increase the success of ICO events we incorporate a dummy variable VC_investor which equals one if a VC investor has been invested into the respective BTBF before or during the ICO event and zero otherwise.

Furthermore, we include a variable Reputation_IPO in order to address the point whether the investor's reputation has a moderating effect or influences the success of a respective venture. Therefore, we apply the share of investments exited via an IPO as investor reputation measurement following Bottazzi et al. (2008), Jackson et al. (2012) and Nahata (2008) which is based on the assumption that IPOs are the most favorable exit option for investors. By incorporating this measure, we refer to the lead investor which is in line with Krishnan et al. (2011) as lead investors maintain the closest relationship to the portfolio company in investor syndicates and thus exert great influence. The calculation of the variable is thereby based on a similar approach as applied by Nahata (2008) and takes the average of the yearly percentage share of IPOs backed by a specific investor compared to all IPOs in the same year. For calculating the reputation, we refer to a timespan from 1990 until 2018.

In order to assess whether an earlier VC backing influences the success of BTBFs we include the variable lnDays1stVCinvtoICO. This variable measures the number of days between the receipt of a first round of VC investment and the ICO. As the variable is highly skewed, we apply the natural logarithm. To examine our hypothesis that CVC investors are beneficial for the development of BTBFs we include a dummy variable CVC_investor that equals one if a venture has received corporate 
Table 1 Definition of variables

\begin{tabular}{|c|c|}
\hline Variable & Description \\
\hline \multicolumn{2}{|l|}{ Control variables } \\
\hline Country & Dummy variables indicating the BTBF's origin \\
\hline Ethereum & $\begin{array}{l}\text { A dummy variable indicating } 1 \text { if the BTBF's technology is based on } \\
\text { Ethereum and } 0 \text { otherwise }\end{array}$ \\
\hline Platform & $\begin{array}{l}\text { A dummy variable indicating } 1 \text { if the BTBF operates a platform business } \\
\text { model and } 0 \text { otherwise }\end{array}$ \\
\hline GDP_growth_fdg & $\begin{array}{l}\text { Variable indicating GDP growth }(\%) \text { in the BTBF's founding year and country } \\
\text { of origin }\end{array}$ \\
\hline \#Founders & Variable indicating the team size at BTBF foundation \\
\hline Whitepaper & $\begin{array}{l}\text { A dummy variable indicating } 1 \text { if the BTBF has disclosed a whitepaper and } 0 \\
\text { otherwise }\end{array}$ \\
\hline preICO & $\begin{array}{l}\text { A dummy variable indicating } 1 \text { if the BTBF has conducted a pre ICO and } 0 \\
\text { otherwise }\end{array}$ \\
\hline BTCprice_fdg & $\begin{array}{l}\text { Variable indicating the average Bitcoin price during the BTBF's founding } \\
\text { quarter }\end{array}$ \\
\hline \multicolumn{2}{|l|}{ Independent variables } \\
\hline VC_investor & $\begin{array}{l}\text { A dummy variable indicating } 1 \text { if the BTBF has received funding from a VC } \\
\text { investor prior or during its ICO and } 0 \text { otherwise }\end{array}$ \\
\hline lnDays1stVCinvtoICO & $\begin{array}{l}\text { Variable indicating the natural logarithm of number of days between the } \\
\text { BTBF's first funding event and BTBF's ICO (days) }\end{array}$ \\
\hline Reputation_IPO & $\begin{array}{l}\text { Variable indicating the average reputation of all lead investors prior and during } \\
\text { BTBF's ICO measured as historical IPO Share }\end{array}$ \\
\hline HHI & $\begin{array}{l}\text { Herfindahl Index for blockchain specialized investors based on the lead inves- } \\
\text { tor within the first three funding rounds }\end{array}$ \\
\hline CVC_investor & $\begin{array}{l}\text { A dummy variable indicating } 1 \text { if the BTBF has received funding from a CVC } \\
\text { prior or during its ICO and } 0 \text { otherwise }\end{array}$ \\
\hline \multicolumn{2}{|l|}{ Dependent variables } \\
\hline Ln_amount_ICO & $\begin{array}{l}\text { Dependent variable indicating the natural logarithm of amount of raised } \\
\text { money (USD) in ICO }\end{array}$ \\
\hline Survived & $\begin{array}{l}\text { Dependent binary variable indicating } 1 \text { if the BTBTF is operating as of } 18 \text { th } \\
\text { April } 2019 \text { and } 0 \text { otherwise }\end{array}$ \\
\hline
\end{tabular}

The table describes the dependent, independent and control variables used

venture capital previous or during its ICO and zero otherwise. This approach is in line with Park and Steensma (2012) who find that particularly ventures that require specialized complementary assets benefit from CVC investors.

Furthermore, in order to elaborate on the question whether blockchain specialized investors impact the success of BTBFs, we incorporate a variable $H H I$ which is the Herfindahl index for the first blockchain-specialized lead investor within the first three funding rounds prior to the ICO. This variable denotes the portfolio concentration of a specific investor. For calculating the Herfindahl index, we refer to all investments conducted by a specific investor prior to the investment in the respective BTBF following a similar approach as Gompers et al. (2009). In particular, we rely on the same industry classification but add blockchain as a separate industry. 
In addition to the independent variables used, this paper also controls for several effects that might influence the success of BTBFs. In order to analyze potential effects that may arise from the founding country, we incorporate country control variables which is in line with Fisch (2019). The dummy variable equals one if the venture's founding location is in the respective country and zero otherwise. The main reason for doing this is that a venture's location is decisive for attracting financial sources such as venture capital (Stuart and Sorenson 2003) or crowdfunding (Mollick 2014), although a stronger online exposure, like in the case of most crowdfunding rounds, seems to reduce potential geographic influences. Furthermore, cluster regions are supposed to support the foundation and development process of new ventures by providing resources and networks (Gilbert et al. 2008). Particularly, Switzerland has established a blockchain-friendly environment (Novak 2019) which might also be beneficial for the foundation of new ventures in this area. Furthermore, we control for the fact whether a BTBF is built on the Ethereum blockchain or not (Ethereum). Therefore, we implement a dummy variable that equals one if the respective venture builds on Ethereum and zero otherwise. Most blockchain related ventures build on Ethereum and offer ERC20 tokens. Ethereum represents a de facto standard and offers certain advantages for ventures which might increase the success probability. By defining a set of rules that transactions need to follow, Ethereum enables a greater interoperability (Fisch 2019) and hence act as an indicator whether a venture is supposed to conduct an ICO (Chen 2018).

Based on the existing research findings that particularly new platform businesses are attractive investment cases for investors (Kenney and Zysman 2019), we control for this in our models (Platform). Generally, asset-light business models are easier to scale and more flexible to adopt to changing environments. Subsequently, BTBFs that operate predominantly as platform provider could also demonstrate to be superior in terms of survival and success of ICO events.

In addition to these control variables, we control for the GDP growth during founding ( $G D P \_g r o w t h \_f d g$ ). Therefore, we take the GDP growth rate of the country of foundation during the founding year from IWF database for each venture in our sample. We apply this control variable as existing research provides certain evidence that the overall economic development has certain implications for the founding behavior as well as for the chance to receive sufficient funding levels. Nanda and Rhodes-Kropf (2013) provide evidence that promising and successful ventures are more often founded during economic'cold' times as times of strong economic growth induce that lower quality ventures also get funded as the overall market development conceals their potential quality issues at first. This effect seems to be additionally enforced by the fact that VC and private equity activity levels are closely related to the global economic development as VCs and private equity firms have higher levels of 'dry powder' at hand which fosters the likelihood for getting funded and achieving high valuation levels (Dias and Macedo 2016).

Besides these controls, we include further the number of founders (\#Founders) as larger founding teams might found higher performing firms (Eesley and Roberts 2012; Eisenhardt and Schoonhoven 1990). Existing research assumes that larger founding teams can contribute better to the venture development through easier functional differentiation and specialization (Eisenhardt and Schoonhoven 1990). 
Furthermore, we add a variable to our model that controls whether the venture has conducted a 'pre-ICO' or not before it conducts the main ICO (preICO). The variable equals one if the venture has conducted a pre-ICO and zero otherwise. During pre-ICOs or 'pre-sales' a small share of tokens is sold to early investors at a discount within a limited time span. To control for the existence of a pre-ICO is quite common in the blockchain research area (Amsden and Schweizer 2018; Fisch 2019; Fisch and Momtaz 2019) and is based on the assumption that word-of-mouth of early investors increases the attention for a venture and in turn increases the success probability of the main ICO. This phenomenon has been widely studied in the area of crowdfunding research (Amsden and Schweizer 2018; Colombo et al. 2015; Vismara 2015) and hence we control for it in our research context.

Most ventures that conduct an ICO prepare and provide prior to the funding event a so-called whitepaper. A whitepaper is usually published by the venture in order to disclose information about IT protocols, adopted public blockchain, token supply, pricing and the distribution mechanism, and details on the project to be developed (eventually a business plan, including a team description) to potential investors (Adhami et al. 2018), similar to a securities prospectus. However, the venture is not obligated to publish such a document but it evolved to a de facto standard. In order to account for the existence of a whitepaper, we include a dummy variable equaling one if the venture has disclosed a whitepaper and zero otherwise (Whitepaper). We assume that disclosing a whitepaper forces ventures to act more self-disciplined and helps them to stay more focused. Nevertheless, producing a whitepaper comes with certain costs for the venture but allows potential investors to assess the success potential easier which makes the investors feel safer when investing besides raising additional attraction. A summary of variables used is outlined in Table 1.

\subsection{Method}

In order to shed light on the collaboration between BTBFs and their investors as well as on respective success determining impacts, we apply the amount of received funding during ICOs as first success measurement. Since we study only BTBFs that have conducted an ICO, our analysis may suffer from a selection bias arising from the fact that unobservable factors might trigger the conduction of ICOs. To account for this potential selection bias and the resulting unobserved heterogeneity, we apply a two-step Heckman correction procedure in our models using the inverse Mill's ratio (Heckman 1976, 1979; Hellmann and Puri 2002). The Heckman two-step method or correction procedure controls for selection by first modeling the decision to be included in a sample or not with a probit model based on individual characteristics (selection equation). Second, the ultimate outcome variable is regressed using least squares on the independent variables and the fitted values from the selection equation, which are in a function called the inverse Mill's ratio (outcome equation) (Verbeek 2004; Wolfolds and Siegel 2019). In our setting, the binary dependent variable $I C O$ is applied (equaling one if the respective BTBF has conducted an ICO and zero otherwise) to derive the inverse Mill's ratio in the selection equation. Based on the residuals of the predicted probabilities of each BTBF to conduct an 
ICO, the inverse Mill's ratio is computed. Second, the inverse Mill's ratio is applied in the outcome regression model in order to account for unobserved heterogeneity and hence, to retrieve more consistent estimation parameters (Colombo and Grilli 2010; Tucker 2010). From a theoretical perspective, the inverse Mill's ratio can be described as the standard deviation of the residuals in the outcome regression model multiplied with the correlation between the error terms in the selection and outcome regression model (Certo et al. 2016). Furthermore, Heckman models should include at least one variable in the selection equation which is not part of the outcome equation. This variable influences the probability of an observation to be included in the sample $(I C O)$ but not the ultimate dependent variable (Ln_amount_ICO) (Sartori 2003). We use the average Bitcoin price during the quarter of foundation of the respective $\mathrm{BTBF}$ as an excluded variable in the outcome equation in order to account for the unobserved heterogeneity. We conjecture that high Bitcoin price levels during the foundation increase the likelihood for BTBFs to conduct an ICO but that it will have no effect on the BTBFs chances to become successful as such. Besides the average Bitcoin price during the foundation quarter (BTCprice $f d g$ ), we include all control variables in the selection equation. Subsequent to the selection model, a second-stage linear regression is conducted including the inverse Mill's ratio. For the second-stage linear regression, we regress the natural logarithm of the amount of ICO funding on all independent and control variables.

Furthermore, in order to apply our dependent success variable Survived, we follow a similar approach to control for a potential selection bias as in the case of the continuous dependent variable. For assessing the impact of our controls and independent variables on the dependent binary success variable Survived we estimate a bivariate probit model with sample selection (Heckprobit) (van de Ven and van Praag 1981). Similar to the approach in the continuous case we estimate a probit model by regressing the ICO variable on a set of independent and control variables that have empirically proven to influence BTBFs' decision to conduct an ICO (selection equation) and include the derived sample selection correction term in our success equation (Sandner et al. 2008; Winston Smith and Robb 2011). The success equation regresses thereby the binary variable Survived on the same set of independent variables and controls as in the continuous case. When $\rho \neq 0$, i.e. there is correlation between error terms of the outcome and selection equation, the standard probit model produces biased results. The Heckprobit procedure instead is intended to correct for selection bias, and to provide consistent, asymptotically efficient estimates for all the parameters in the model.

\section{Empirical results}

\subsection{Descriptive statistics}

As already outlined above, BTBFs and ICOs represent a rather new phenomenon. Figure 1 indicates that the number of foundations of BTBFs has peaked in 2017 and declined notably thereafter. 


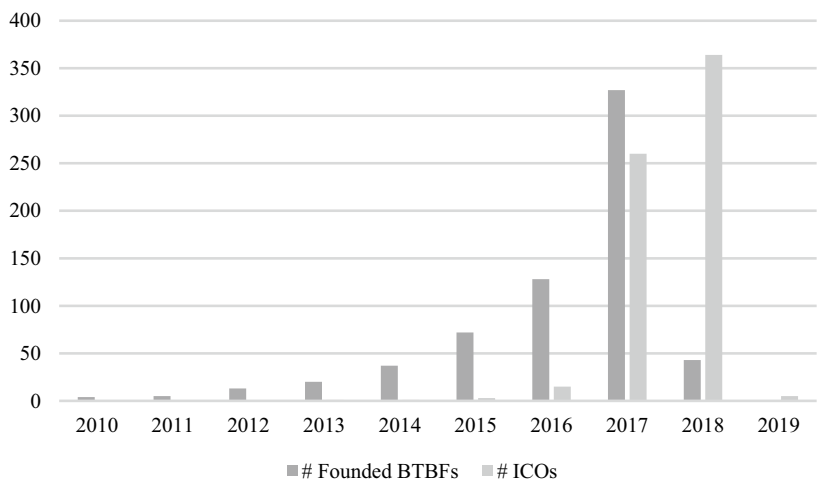

Fig. 1 Development of number of founded BTBFs and number of ICOs

Table 2 Industry overview of VC-backed and non-VC-backed BTBFs

\begin{tabular}{|c|c|c|c|c|c|c|}
\hline \multirow[t]{2}{*}{ Industry } & \multicolumn{2}{|c|}{ All BTBFs } & \multicolumn{2}{|c|}{ BTBFs w/o VC backing } & \multicolumn{2}{|c|}{ BTBFs w/ VC backing } \\
\hline & $\begin{array}{l}\text { N. of } \\
\text { firms } \\
\text { (abs.) }\end{array}$ & $\begin{array}{l}\text { N. of firms (in } \\
\% \text { ) }\end{array}$ & $\begin{array}{l}\text { N. of } \\
\text { firms } \\
\text { (abs.) }\end{array}$ & $\begin{array}{l}\text { N. of firms (in } \\
\% \text { ) }\end{array}$ & $\begin{array}{l}\text { N. of } \\
\text { firms } \\
\text { (abs.) }\end{array}$ & N. of firms (in \%) \\
\hline Consulting & 31 & 4.78 & 22 & 4.71 & 9 & 4.95 \\
\hline Energy & 7 & 1.08 & 6 & 1.28 & 1 & 0.55 \\
\hline Environmental & 3 & 0.46 & 3 & 0.64 & 0 & 0.00 \\
\hline $\begin{array}{l}\text { Financial ser- } \\
\text { vices }\end{array}$ & 236 & 36.36 & 178 & 38.12 & 58 & 31.87 \\
\hline Healthcare & 14 & 2.16 & 11 & 2.36 & 3 & 1.65 \\
\hline IT technology & 159 & 24.50 & 90 & 19.27 & 69 & 37.91 \\
\hline $\begin{array}{l}\text { Media \& Mar- } \\
\text { keting }\end{array}$ & 142 & 21.88 & 114 & 24.41 & 28 & 15.38 \\
\hline $\begin{array}{l}\text { Public adminis- } \\
\text { tration }\end{array}$ & 7 & 1.08 & 6 & 1.28 & 1 & 0.55 \\
\hline Real estate & 11 & 1.69 & 7 & 1.50 & 4 & 2.20 \\
\hline $\begin{array}{l}\text { Supply chain \& } \\
\text { Logistics }\end{array}$ & 22 & 3.39 & 17 & 3.64 & 5 & 2.75 \\
\hline Others & 17 & 2.62 & 13 & 2.78 & 4 & 2.20 \\
\hline Total & 649 & 100 & 467 & 100 & 182 & 100 \\
\hline
\end{tabular}

The table shows an overview of industry affiliation separated by the total sample (column 1), BTBFs with VC (column 2) and BTBFs without VC (column 3)

Furthermore, Fig. 1 shows that the number of conducted ICOs has risen particularly in 2017 and 2018 whereas a reduced level of activity can be observed in Q1 2019. Subsequently, it is observable that the number of ICOs follows the number of BTBFs foundations and hence, a strong preference of BTBFs to conduct ICOs as important funding resource. The strong increase of ICOs is thereby in line with the findings of Fisch (2019) who also present a peak of ICO activity in the first half 
of 2018 which indicates that the datasets of BTBFs that have completed an ICO are consistent to a certain degree.

The BTBFs included in our sample operate in a variety of industries but predominantly in the financial services industry (36.36\%), followed by the IT technology sector (24.50\%) (Table 2). Overall, 182 BTBFs out of 649 BTBFs received funds from a financial investor prior or during their ICO but we do not find any material differences in the industry distribution when comparing BTBFs that have received VC proceeds and those that have not.

When regarding the geographical distribution of the BTBFs in our sample, 124 BTBFs are located in the US, followed by Singapore (70 BTBFs), and UK (57 BTBFs). Overall, the geographical distribution of BTBFs seems to be highly skewed and concentrated in certain regions.

Table 3 presents the detailed descriptive statistics for all variables employed in our model. Further, we include in this table t-tests between the BTBFs that have conducted an ICO and those that have not conducted an ICO but which are included in the respective selection equations of our models. The t-tests indicate thereby that BTBFs that have conducted an ICO and those that have not differ to a certain extent regarding the variables considered in our models. In particular, we find significant differences for the investor-related variables e.g. VC_investor, Reputation_IPO, $C V C \_$investor. Finally, Table 4 shows the correlation matrix for all variables and observations that are considered in our model.

\subsection{Main results}

First of all, in order to verify whether or not the combination of variables suffers from multicollinearity, variance inflation factors (VIF) are derived for the probit as well as the OLS regression model. Due to the fact that mean VIF values of the models lie below the suggested threshold level of five as suggested by Chatterjee and Hadi (2006) and the maximum VIF values below the threshold level of ten as suggested by O'brien (2007), multicollinearity does not seem to be an issue.

Table 5 presents our main results referring to our focal variable Ln_amount_ICO as dependent variable which is a widely accepted success measurement for BTBFs (Fisch 2019; Fisch and Momtaz 2019), comparable to the amount of funding in crowdfunding campaigns or IPOs.

Model 1 presents thereby the results of the probit estimation which is used to generate the inverse Mill's ratio, i.e. the selection equation. Therefore, the binary dependent variable $I C O$ is regressed on all control variables as well as the Bitcoin price during the founding quarter which has proved empirically to influence the likelihood for BTBFs to conduct an ICO. For reasons of brevity we present only one selection equation for all models as the probit estimation yields identical results for all models.

Models 2-6 show the hierarchical regressions in order to test our hypotheses whereas model 7 presents the full model including all controls and independent variables. Furthermore, model 8 presents the results of a linear OLS with the 
Table 3 Summary statistics of BTBFs

\begin{tabular}{|c|c|c|c|c|c|c|c|}
\hline \multirow{2}{*}{$\begin{array}{l}\text { Summary } \\
\text { statistics }\end{array}$} & \multicolumn{3}{|c|}{ Panel A: BTBFs with ICO } & \multicolumn{3}{|c|}{ Panel B: BTBFs without ICO } & \multirow{2}{*}{$\begin{array}{l}\text { Panel C: } \\
\text { comparison of } \\
\text { means } \\
\text { t-value }\end{array}$} \\
\hline & $\begin{array}{l}\text { Observa- } \\
\text { tions }\end{array}$ & Mean & Std. Dev & $\begin{array}{l}\text { Observa- } \\
\text { tions }\end{array}$ & Mean & Std. Dev & \\
\hline \multicolumn{8}{|l|}{ Control } \\
\hline Ethereum & 649 & 0.703 & 0.458 & 82 & 0.488 & 0.503 & $-3.961 * * * *$ \\
\hline Platform & 649 & 0.182 & 0.386 & 82 & 0.378 & 0.488 & $4.201 * * * *$ \\
\hline $\begin{array}{l}\text { GDP_- } \\
\text { growth_- } \\
\text { fdg }\end{array}$ & 649 & 2.722 & 1.685 & 82 & 2.762 & 1.613 & 0.205 \\
\hline \#Founders & 649 & 2.194 & 1.115 & 82 & 2.073 & 1.497 & -0.887 \\
\hline $\begin{array}{l}\text { Whitepa- } \\
\text { per }\end{array}$ & 649 & 0.524 & 0.500 & 82 & 0.537 & 0.502 & 0.217 \\
\hline preICO & 649 & 0.359 & 0.480 & 82 & 0 & 0 & $\mathrm{n} / \mathrm{a}$ \\
\hline $\begin{array}{l}\text { BTCprice_ } \\
\text { fdg }\end{array}$ & 649 & 2214.544 & 3051.183 & 82 & 1816.583 & 3131.875 & -1.110 \\
\hline \multicolumn{8}{|l|}{ Independent } \\
\hline $\begin{array}{l}\text { VC_inves- } \\
\text { tor }\end{array}$ & 649 & 0.280 & 0.450 & 82 & 0.402 & 0.493 & $2.290 * *$ \\
\hline $\begin{array}{l}\text { InDays1st- } \\
\text { VCinv- } \\
\text { toICO }\end{array}$ & 649 & 1.090 & 2.253 & 82 & 0 & 0 & $\mathrm{n} / \mathrm{a}$ \\
\hline $\begin{array}{l}\text { Reputa- } \\
\text { tion_IPO }\end{array}$ & 649 & 0.0001 & 0.001 & 82 & 0.0003 & 0.002 & $2.666^{* * * *}$ \\
\hline HHI & 649 & 0.053 & 0.161 & 82 & 0.065 & 0.177 & 0.613 \\
\hline $\begin{array}{l}\text { CVC_inves- } \\
\text { tor }\end{array}$ & 649 & 0.026 & 0.160 & 82 & 0.122 & 0.329 & $4.383^{* * * *}$ \\
\hline \multicolumn{8}{|l|}{ Dependent } \\
\hline Survived & 649 & 0.955 & 0.207 & 82 & 0.915 & 0.281 & -1.605 \\
\hline $\begin{array}{l}\mathrm{Ln}_{-} \\
\text {amount_- } \\
\mathrm{ICO}\end{array}$ & 649 & 1.090 & 0.089 & 82 & $\mathrm{n} / \mathrm{a}$ & $\mathrm{n} / \mathrm{a}$ & $\mathrm{n} / \mathrm{a}$ \\
\hline
\end{tabular}

The table shows all model variables for BTBFs that have conducted an ICO and BTBFs which have not conducted an ICO

$* \mathrm{p}<0.10, * * \mathrm{p}<0.05, * * * \mathrm{p}<0.01, * * * * \mathrm{p}<0.001$

natural logarithm of the funded ICO amount as dependent variable in order to provide comparability with the remaining results that consider potential selection bias and the occurrence of endogeneity.

Further, Table 6 presents our results when referring to our second dependent success measure variable Survived. Model 1 presents again the identical results from the first stage probit regression. Models 2 to 5 show the results of the hierarchical bivariate probit regression models. Due to brevity, we present only the coefficients for the outcome equations. Model 7 presents the results of the full 


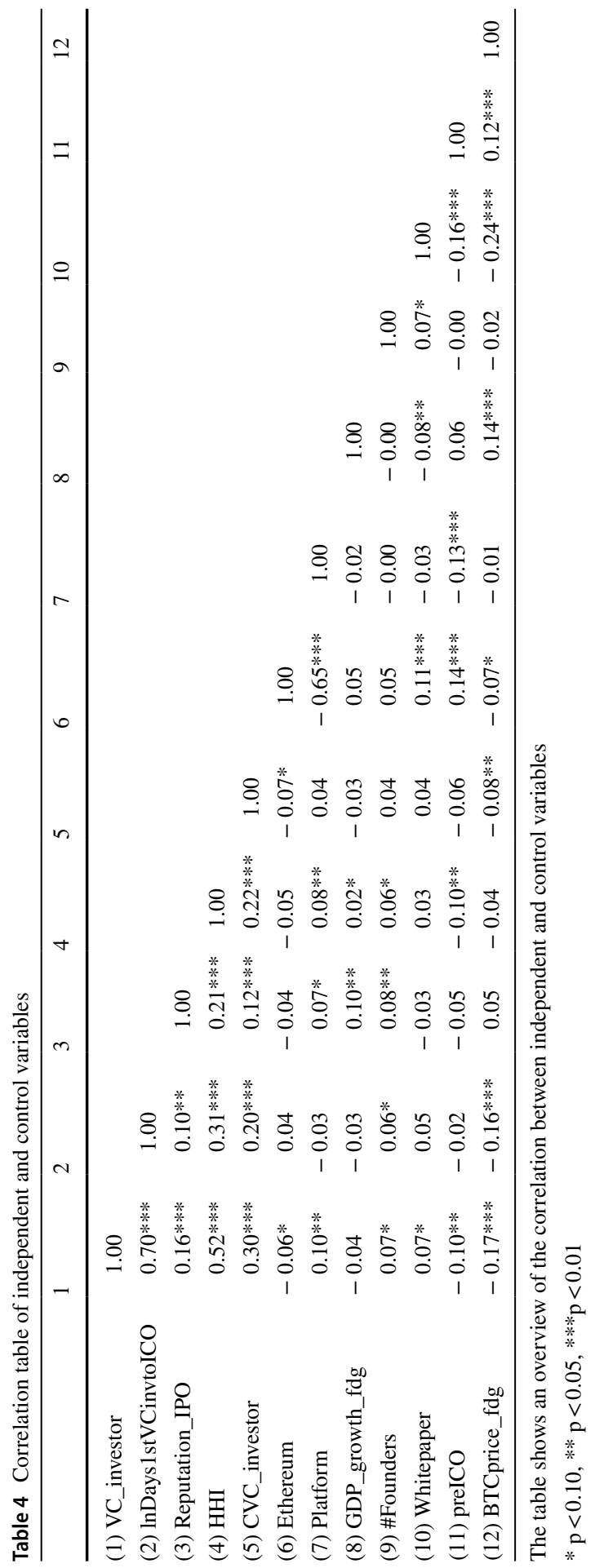




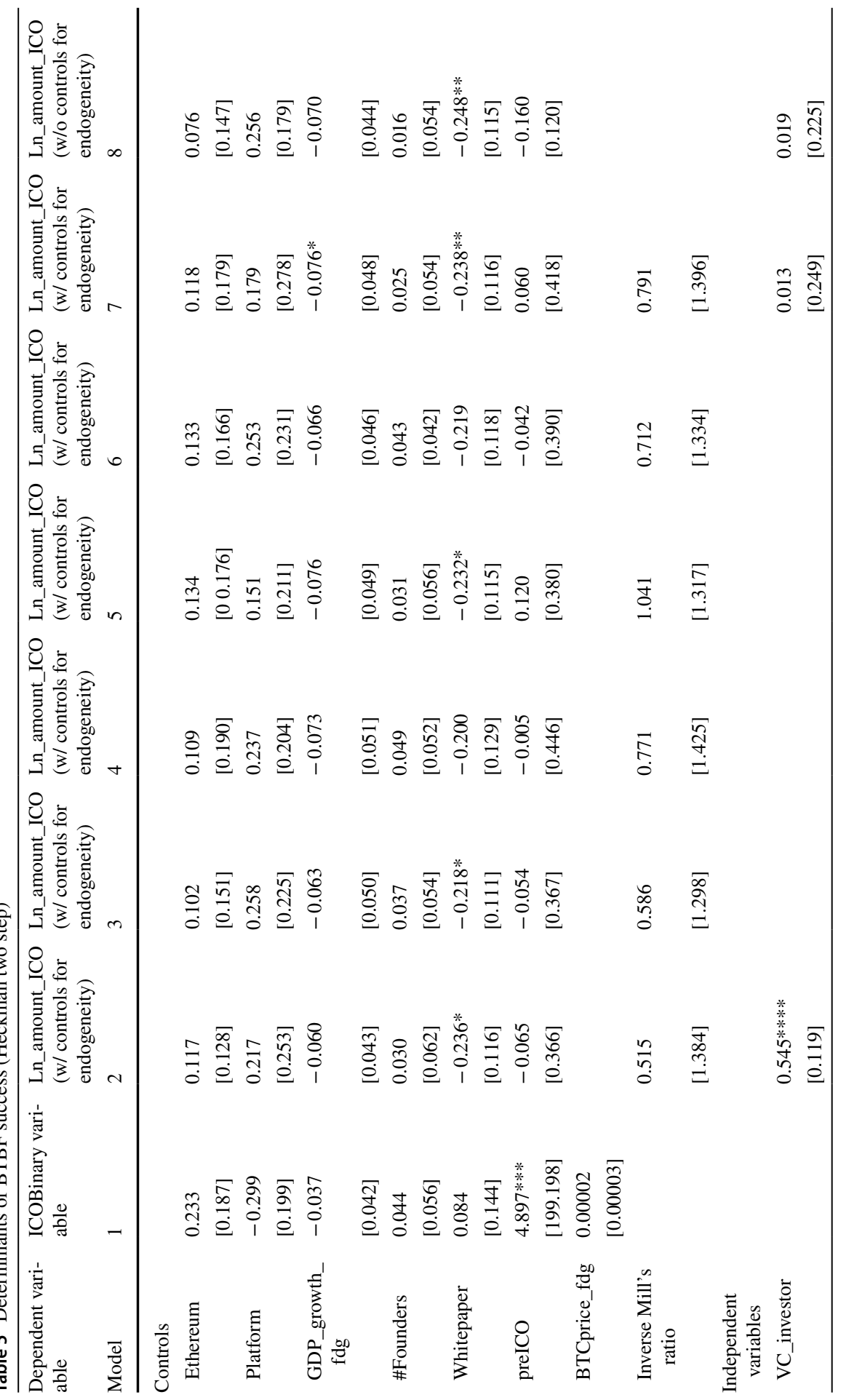




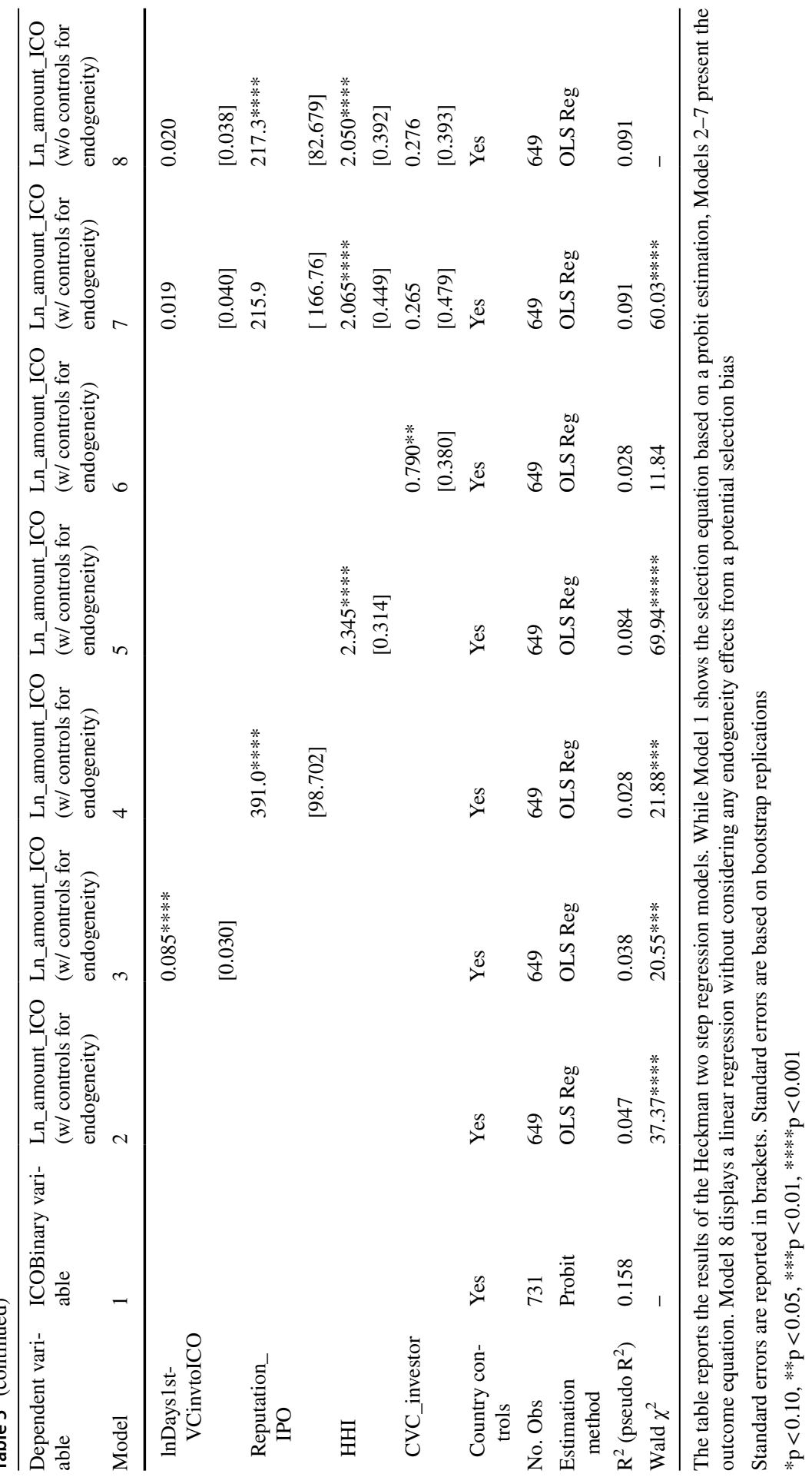


model whereas model 8 presents the results of a probit model without considering any selection and treatment effects for reasons of comparability similar to the approach followed in the Heckman two step OLS regression.

When the amount of ICO funds raised is considered (Heckman two-step) as success measure (Ln_amount_ICO), model 2 reveals that the variable VC_investor has a positive and highly significant effect at the $0.1 \%$ level. This effect remains positive in the full model (model 7), however the statistical significance diminishes. In other words, the existence of a VC investor prior or during the ICO enables the BTBF to increase the amount of money that is received during the ICO funding event.

Further, we find that the time between the first VC investment and the ICO has a positive and highly significant effect at the $0.1 \%$ level on the success of the BTBF (model 3). The effect remains significant in model 8, however, with a negative sign at the $5.0 \%$ significance level. In addition to this, model 4 presents that the average IPO share of the investors prior or during the ICO as well as the respective degree of specialization (model 5) have a positive and highly significant influence on the amount of funding during the ICO at a $0.1 \%$ level. In particular the results regarding the degree of specialization expressed as Herfindahl index of the blockchain-specialized lead investor within the first three funding rounds (prior to the ICO) remains statistically significant at the $0.1 \%$ level in our full model (model 7).

Lastly, the empirical findings detect a positive and highly significant effect at the $0.1 \%$ level of the variable $C V C \_$investor on the amount of funding raised during the ICO. Again, this effect is positive and significant at the $0.1 \%$ level when referring to models 6 and 7 .

Concerning the control variables, we find that the dummy variable Whitepaper is negative on statistically weak levels throughout all models except for models 4 and 6 . Second, the dummy variable preICO has a statistically positive effect in all models. Throughout all models the Inverse Mill's ratio remains positive without any relevant statistical significance which indicates that sample selection does not play a major role. However, the results of the Wald $\chi^{2}$ test indicate the appropriate use of a Heckman two step approach anyhow.

Further, when the binary dependent variable Survived is considered as success measure (bivariate probit models; Table 6), results differ from those presented above. First, we cannot find any statistically significant effect that the investment of a VC investor prior or during the ICO impacts the survival probability of BTBFs that have conducted an ICO (model 1). Second, we find that the time between the VC investment and ICO has a negative impact on the survival probability at a $5.0 \%$ level (model 2). This holds also in the full model (model 6). In addition, we do not find any statistically significant effect that the investor's reputation (model 3) or the existence of a CVC investor (model 5) has an impact on the survival probability. Despite of being statistically insignificant, we find in model 2 that having received funds from a VC investor prior or during the ICO lowers the likelihood to survive in the mid-term by $1.3 \%$. Furthermore, we find ambiguous results for $\mathrm{CVC}$ investors as well as model 6 indicates that having 


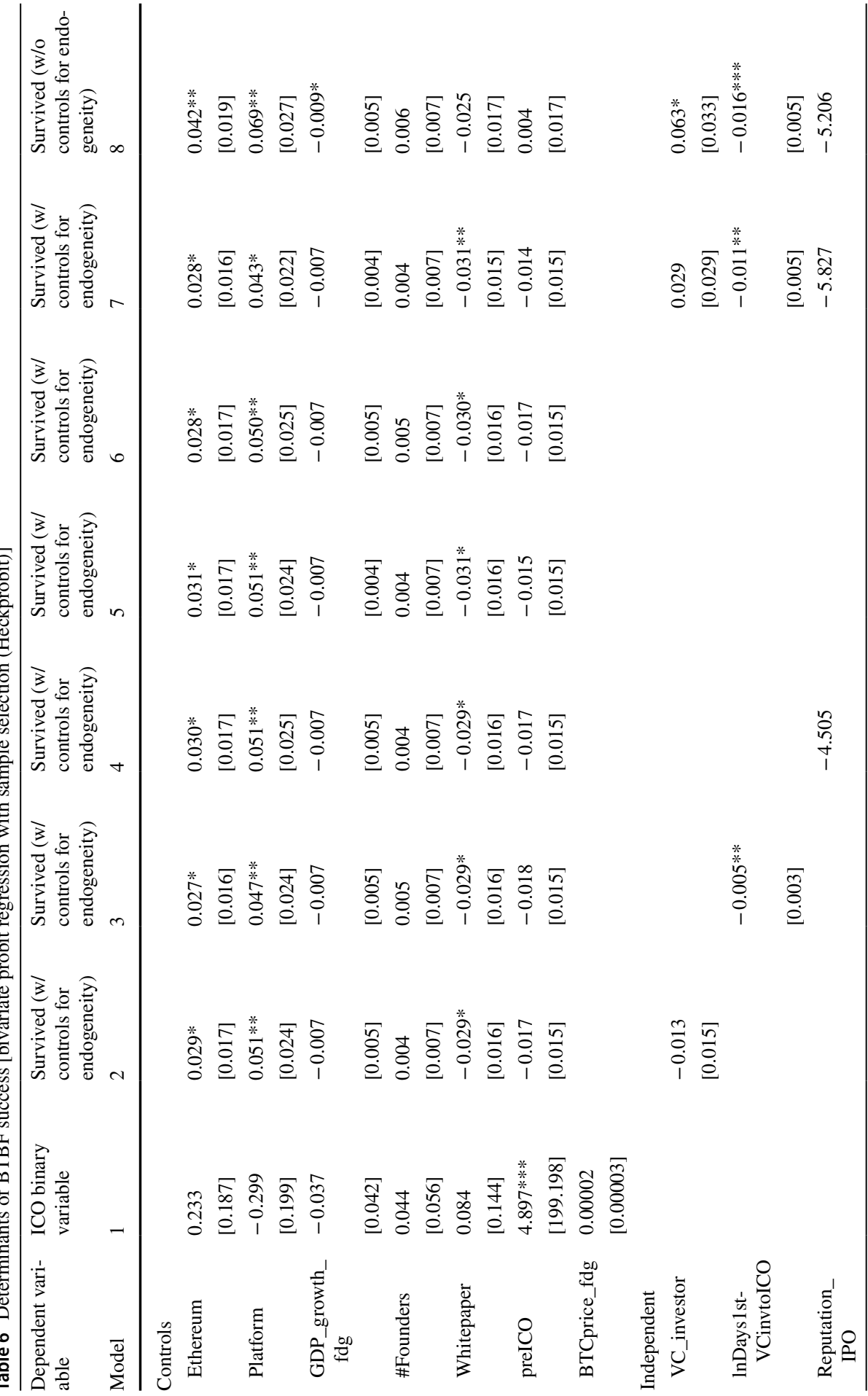




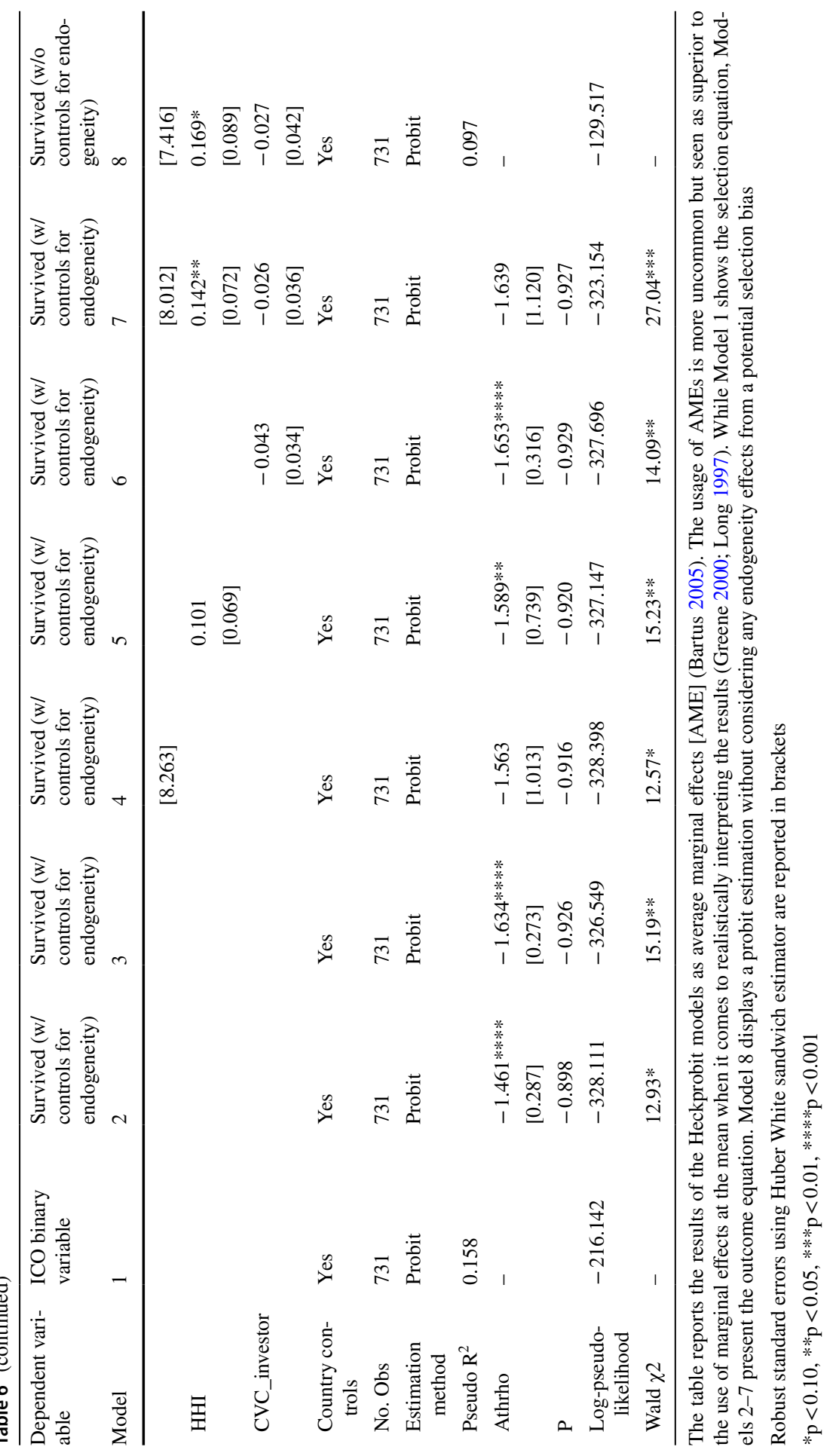


received funds from a CVC investor prior or during the ICO lowers the likelihood to survive in the mid-term by $4.3 \%$.

Generally, this raises the question why the results differ between the short-term (Ln_amount_ICO) and mid-term (Survived) view. Besides the fact that our results might be influenced by the rather short period of time between the ICO of respective BTBFs and the assessment whether they are still operating, we assume that the certification effect (Baum and Silverman 2004; Megginson and Weiss 1991) which results from the investment of $\mathrm{VC}$ investors prior or during the ICO is particularly important in the context of BTBFs. More precisely, based on the finding that the existence of a VC investor has a significantly positive influence on the success of an ICO, while the existence of an VC investor among the BTBF's investor universe has a negative, although statistically insignificant, influence on the mid-term survival probability of BTBFs, indicates that $\mathrm{VC}$ investors attract additional investors in ICO processes but that they are not able to support BTBFs appropriately in the mid-term. One potential explanation for this effect could be that most VC investors lack sufficient industry-specific knowledge and focus rather on attractive short-term exit opportunities. Furthermore, considering the results of $\mathrm{VC}$ investors' treatment time (time between VC investment and ICO), we find a statistically significant and positive influence on the success of ICOs, while we find in contrast to this a statistically significant and negative influence on the mid-term survival probability of BTBFs. This effect can be regarded as in line with the prior finding and indicates to a certain extent that $\mathrm{VC}$ investors might be primarily interested in high valuations and support BTBFs on this path while they do not use an extended investment duration to anticipate mid-term development opportunities and support BTBFs' survival. On the other side and interestingly, we find again support in the full model (model 6 ) that the investor specialization has a positive and statistically significant impact at the $5.0 \%$ level on the survival probability of BTBFs. This finding underlines our assumption that technical knowledge is crucial to support BTBFs and that today's VC investors might face certain knowledge limitations and boundaries against the background of blockchain due to the novelty of this technology which implies that primarily specialized investors can give valuable advice and contribute to the development of BTBFs. The importance of technical knowledge in BTBF contexts gives also an indication why the reputation of investors seems not to be linked to the midterm development of their BTBF portfolio companies as their reputation was initially built upon more established industries caused by past transactions (Nahata 2008). Further, networks of more reputable investors, which have historically proven to be beneficial for portfolio companies' development (Hsu 2004; Lindsey 2002) might be less effective due to the novelty and the decentralized structure of the blockchain sector.

Concerning the control variables, we find again a statistically negative impact (at the 5.0 to $10.0 \%$ level) of the control variable Whitepaper throughout all models. Further the dummy variables Ethereum and Platform show a statistically positive impact at the 5.0 to $10.0 \%$ level in all models. In contrast to the Heckman two-step OLS models, the bivariate probit models confirm clearly the assumption of an existing sample selection bias as in almost all models (except for model 3 and 6) athrho has a negative coefficient and is statistically significant at the $0.1 \%$ level and 
hence indicates that selection on unobserved variables is identified and present in the models (Holm and Jaeger Meier 2010). More specifically, that means that the completion of an ICO is non-random and the decision to execute an ICO is based on factors being unobservable. Thus, applying a Heckman correction method (Certo et al. 2016; Heckman 1979) accounts for this unobserved heterogeneity when focusing solely on BTBFs that have completed an ICO.

\subsection{Robustness}

In order to test the robustness of our results, we apply additional analyses to take care of a potential selection bias and unobserved heterogeneity arising from the nature of our dependent variable. Following Colombo and Grilli (2010) and Vella and Verbeek (1999), we apply a control function approach. For this approach, a control factor, literally the estimate of the generalized residuals, is computed for BTBFs that have conducted an ICO as well as for BTBFs that have not conducted an ICO using a probit regression regarding the existence of an ICO. We include the residual (ICO Lambda) into our outcome equation (in addition to all other covariates) including the dummy variable ICO. Subsequently, a positive correlation of the error terms in the selection equation and the success equation would lead to a positive coefficient for the residual lambda (Colombo and Grilli 2010) mitigating potential selection bias. Based on the control function approach, we can confirm our results widely. In particular, we can confirm that there exist obviously rarely systematic factors that foster the decision of BTBFs to conduct an ICO which impact the amount of received funding in the ICO event as we cannot find any indication for a potential selection bias. Furthermore, we can confirm that all effects remain significant except for the receipt of CVC. The respective results are not tabulated for the sake of brevity but can be provided upon request.

In addition to the application of the control function approach, we apply additional variables measuring the reputation of investors as robustness tests. Based on previous research, we apply the average age of investors as well as the average number of portfolio companies as proxy for the reputation of investors. Both covariates show positive coefficients but lose their high significance. However, we assume that this could be mainly due to the fact that blockchain investors are rather young in general given the nascent state of the technology. The results are not tabulated but are available upon request.

Overall, we presume that our findings are robust but subject to the general limitations that every empirical contribution faces particularly in new research domains.

\section{Discussion and conclusion}

\subsection{Discussion of the main results}

Based on the introduced variables and methods, this section provides a summary of the empirical results derived from both the Heckman two-step models as well 
as from the bivariate probit models. Based on our results (Table 5 models 2-7), we find that obviously no material selection bias exists when assessing if unobserved heterogeneity impacts the decision of BTBFs to conduct an ICO and the subsequent amount of funding. Following existing research, a potential selection bias is only weak or minor as the inverse Mill's ratio is not statistically significant throughout all our models (models 2-7). We assume that this can be an indication that BTBFs are facing lower hurdles when conducting an ICO compared to the hurdles which ventures are usually facing when accessing other means of funding as in other entrepreneurial research contexts often a clear selection effect can be observed (Bertoni et al. 2011; Certo et al. 2016). Furthermore, we assume that lower hurdle rates for completing an ICO compared to other funding types caused by a lack of due diligence processes (Kranz et al. 2019), lower or no regulatory requirements (Rhue 2018) and smaller influence of individual investors animate a considerable number of BTBFs to pursue an ICO including those of lower quality which may not fulfill required quality criteria of other funding events, e.g. VC financing rounds or IPOs. Hence, from an investor perspective (during an ICO), a diligent target firm evaluation is highly recommended.

However, in contrast to this finding, we find indications for a selection bias and obviously unobserved effects when examining BTBFs that have conducted an ICO and their later survival (Table 6). Actually, this means that unobserved effects influence the chance of completing an ICO as well as the likelihood to survive and thus that BTBFs that have completed an ICO differ from those that have not completed an ICO based on unobservable factors. Based on these results, we conclude that the ICO itself helps the BTBFs to survive at least in the mid-term as the ICO event provides usually sufficient proceeds, leading to the situation that BTBFs that have conducted an ICO exhibit a higher survival rate compared to those that have not conducted an ICO whereas the decision to conduct an ICO is less related to the amount of received funding.

Furthermore, we find strong support for hypothesis 1 that a VC investor increases the success of BTBFs (Table 5 model 2). This is in line with the findings of Fisch and Momtaz (2019) who also find strong evidence that financial investors are beneficial for the development of BTBFs. We presume that the provision of managerial capabilities and past experiences in the blockchain area helps their portfolio BTBFs to grow and to become more successful than others. This finding is further supported by findings in line with hypothesis 2 that longer treatment periods have a significantly positive impact on the success of BTBFs. We conclude from this result that a longer provision of managerial capabilities and support can lead to a stronger transfer of knowledge and subsequently increases the BTBF's success measured as amount of ICO funding. However, we do not find similar results when reviewing the results of the bivariate probit models by applying Survived as dependent variable (Table 6). We find no significant effect for the existence of a VC investor prior or during the ICO and a negative effect for the time between the investment and the ICO event. Subsequently, VC investors seem not to influence the mid-term success of BTBFs if they have conducted an ICO. We assume again that the proceeds of ICOs conceal other influences, in particular as the time between the ICO event and the date of our assessment is rather short. 
In addition to this, we find certain support for hypothesis 3 that more reputable investors increase the BTBF's success. However, we find this significantly positive effect only when considering the investor's IPO share as proxy for his reputation but not when considering the age or the number of portfolio companies. These mixed results might be explained by the material difference in those proxy measures of reputation. The investor's IPO share is a measure including a quality component by the investor's ability to conduct an IPO whereas measures such as simply the investor's age or its number of investments is a measure rather focusing on the investor's mere experience without a quality outcome. Another reason for these mixed results can be ascribed to the nascent stage of the blockchain technology. Investors in the blockchain area are assumed to be rather nascent as well and hence reputation proxies that have proved to be reliable historically might lead to these results. Hence, hypothesis 3 can be supported only partially but indicates that BTBFs that have received investments from renowned top investors exhibit higher ICO funding amounts, probably mainly due to a certification effect (Megginson and Weiss 1991) that boosts the ICO development. Further, assessing the mid-term influence of the reputation of investors (Table 6 model 4) adds to the mixed results as we do not find any support for hypothesis 3 in the bivariate probit models. This indicates again that the proceeds of ICOs might conceal other effects as well and hence that the investors' reputation plays a limited role due to the nascent technology.

In contrast to this, we find strong support for hypothesis 4 that more specialized investors increase the success of BTBFs. Based on our results, we conclude that blockchain-specialized investors are able to provide better support and guidance to their BTBF portfolio companies. Hence, superior and specialized industry knowledge seems to be decisive in the area of blockchain which is in contrast to other research in the entrepreneurial finance area as investor specialization is usually considered less crucial (Hagendorff et al. 2009). This finding is also supported when assessing the results of the BTBFs' success measured as their mid-term survival (Table 6 model 5). Furthermore, we do not find any curvilinear relationship between the BTBFs' success and the investors' industry specialization as suggested by Matusik and Fitza (2012). Based on these findings, we conclude that maintaining a certain technology expertise helps investors to support their portfolio BTBFs by providing them with more and higher quality know-how and assets leading to more success in the short- as well as in the mid-term. Nevertheless, we cannot rule out completely or detangle from these findings that this knowledge helps also to identify more promising BTBFs and how fast existing knowledge ages due to the rapid technological development.

Lastly, we find support for hypothesis 5 that CVC investors have a positive influence on the development of BTBFs. We see that the investment of a CVC investor prior or during the ICO represents predominantly a certification for other investors signaling a certain level of quality. Combining the results regarding hypothesis 5 with the remaining results, we conjecture that the access to complementary assets is relevant and leads to positive influences on the BTBF's success. However, when regarding the variable Survived as dependent variable (Table 6 model 6), we cannot confirm these findings as we do not find any significant effect for the existence of CVC investors among the BTBF's investor universe prior or during the ICO. This 
points at the short-term nature of the relevance of certifications provided by the investments of CVC investors whereas effects resulting from the access to complementary assets might be more important in the long-term which is less observable in our sample yet due to the nascent nature of all BTBFs.

\subsection{Contributions to theory and implications for practice}

This study adds to the literature on entrepreneurial finance and more specifically on the relationship of ICOs and more established means of funding. While previous research has focused on ICOs as a new way of financing and compared characteristics of ICOs with more established funding procedures, research that examines the interplay of ICOs and financial investors is rather limited. To our knowledge Fisch (2019) is one of only very few studies that highlights the influence of VCs on BTBFs. However, our study provides a more nuanced view on the success determining factors and studies different types of investors. From a theoretical perspective, we draw on two well-established concepts. First, our study is based on the resource based-view and second, we build upon the signaling theory.

By drawing on the resource based view (Dushnitsky and Lavie 2010; Lavie 2006; Peteraf 1993), we can confirm the transferability of existing findings from a more general entrepreneurial finance context to the blockchain setting. Our results provide a clear indication that the provision of complementary assets is beneficial for the development of BTBFs which is in line with Alvarez-Garrido and Dushnitsky (2016), who demonstrate the impact of providing complementary assets on innovation rates. Thereby, our findings shed light on the benefits of different investor types indicating that more reputable investors are more beneficial than others. Combining these findings with the fact that CVCs seem to have a more significant influence on BTBFs' success suggests the superior importance of specialized technical and market knowledge leading to the conclusion that the access to complementary assets is key. Furthermore, our findings support the resource-based view by highlighting the fact that a longer investment period, i.e. a longer treatment period, has a positive influence on the BTBFs' success. In particular, if one combines our findings with earlier findings that VC investors are not able to select superior BTBFs per se but generate value through their treatment (Fisch and Momtaz 2019), our findings gain additional significance. Summarizing our findings, we can confirm the success relevance of investors in particular if they are able to provide access to complementary assets in order to close existing lacks of resources.

Furthermore, our results add also to the signaling theory established by Spence (1973), as we provide certain evidence that VC investors who are invested before or during the ICO send a signal to other ICO investors regarding the quality of the respective BTBF. By doing this, we can confirm existing research results that investors generate signals to other investors (Gulati and Higgins 2003; Hoenig and Henkel 2015; Stuart et al. 1999) and that those findings hold also in the area of blockchain technology. In addition to this, we assume also that the signal that is generated when a VC investor conducts an investment into a BTBF is received by other stakeholders 
of the BTBF supporting the BTBF's further development. Especially, the signal can help to attract new highly skilled employees and to broaden the customer base as the VC investment represents a certification (Megginson and Weiss 1991). Moreover, this certification gains additional importance due to a lack of signals which emerge from regulatory obligations such as audited accounts which exist in other funding contexts (Momtaz 2020).

\subsection{Limitations and avenues for further research}

Although our study provides significant and robust results, this empirical contribution is subject to certain limitations. First, although we assume to have a rather comprehensive dataset, we are facing the general issue of data scarcity in the research area of entrepreneurial finance (Kaplan and Lerner 2016). In particular, this scarcity comprises detailed information about how the collaboration between BTBFs and potential VC investors is designed on an operational level. In addition, although our sample seems to exhibit a good coverage of relevant BTBFs, that is at least on the level of comparable research, we cannot rule out completely to miss small BTBFs that have stopped operations without conducting an ICO due to the availability of relevant data.

Second, as BTBFs are a rather new phenomenon, research opportunities remain limited whether the development of BTBFs is sustainable or not. Of course, by using the amount of ICO funding as success measure, our study applies an independently confirmed success evaluation. However, even in cases of high ICO funding amounts, a mid- to long-term outlook whether the respective venture remains successful is hardly possible due the overall nascent stadium of the technology. This is accompanied by the fact that many BTBFs are in the product development phase or even in a concept phase when concluding their ICO (Kaal and Dell'Erba 2017). Hence, future research can investigate how ICO funding levels are connected with the future venture performance. Thereby, future research might provide answers to the question whether BTBFs with high ICO funding levels outperform their peers or whether BTBFs with higher ICO funding levels are able to release products earlier, i.e. they are able to generate operating cash-flows earlier. Further, when assessing the mid-term success of BTBFs by considering their survival rate, the significance of our findings might suffer from the rather short period of time between the date of the ICO event and the date for assessing whether the respective BTBF is still operating i.e. has survived. This effect might be further strengthened as potentially high proceeds from the ICO might conceal other influencing factors in the mid-term. We would like to encourage future research to expand the assessment period in order to provide more nuanced views on the mid- to long-term development of BTBFs.

Lastly, although existing research in the area of entrepreneurial finance and in particular in the area of blockchain has provided evidence that VC and other 
early stage investors are not per se able to select superior ventures (Bertoni et al. 2011; Colombo and Grilli 2010; Cumming and Johan 2007; Puri and Zarutskie 2012), we cannot completely rule out that our findings suffer from a potential selection bias when interpreting effects arising from CVC and financial investors. In particular, although our findings provide clear evidence that financial and CVC investors are beneficial for the development of BTBFs, we cannot answer the question how investors should interact with BTBFs on an operational level, especially with regard to the anonymous business characteristics. Thus, we assume that providing a more nuanced view on these effects represents a good avenue for future research.

This aspect leads towards potential avenues for future research. We assume that future research will benefit largely if new empirical studies consider BTBF more generally instead of focusing on BTBFs that have received other means of financing in addition to their ICO. Although our study controls for unobserved heterogeneity arising from potential selection bias by including the inverse Mill's ratio, enlarging the dataset can provide additional and more nuanced insights, especially when taking BTBFs' characteristics into success consideration. Particularly, it can be interesting to see whether factors that have proven to influence the success probability of ventures are also valid in the research area of blockchain related research. Potential characteristics can be technical capabilities demonstrated by the possession of relevant patents as well as the influence of human capital on BTBFs' success. The latter presents an interesting avenue for future research as the blockchain principles rely on anonymity to a large extent but existing research in the entrepreneurial area has shown the significance of human capital for the venture itself as well as decisive criteria for investors (Bottazzi et al. 2008; Homburg et al. 2013).

Further, for BTBFs that have received funding from investors, we encourage future research to disentangle the effect that results from investors' treatment from the signal effect that may be generated by the investment and that attracts other investors. However, this does not only include VC and CVC investors but also all ICO investors instead. Currently, very little is known about ICO investors and it remains unclear whether the assumptions taken from the more general crowdfunding area can be transferred to the ICO context (Fisch 2019). An in-depth examination of ICO investors by conducting surveys or interviews can contribute to the understanding of ICO dynamics and shed light on the driving factors of high funding amounts.

Funding Open Access funding enabled and organized by Projekt DEAL.

Open Access This article is licensed under a Creative Commons Attribution 4.0 International License, which permits use, sharing, adaptation, distribution and reproduction in any medium or format, as long as you give appropriate credit to the original author(s) and the source, provide a link to the Creative Commons licence, and indicate if changes were made. The images or other third party material in this article are included in the article's Creative Commons licence, unless indicated otherwise in a credit line to the material. If material is not included in the article's Creative Commons licence and your intended use is not permitted by statutory regulation or exceeds the permitted use, you will need to obtain permission 
directly from the copyright holder. To view a copy of this licence, visit http://creativecommons.org/licen ses/by/4.0\%.

\section{References}

Achleitner A-K, Braun R, Kohn K (2011) New venture financing in Germany: effects of firm and owner characteristics. Z Betriebswirtsch 81:263-294. https://doi.org/10.1007/s11573-011-0441-3

Achleitner A-K, Braun R, Lutz E, Tappeiner F (2018) Private equity group reputation and financing structures in German leveraged buyouts. J Bus Econ 88:363-392. https://doi.org/10.1007/s1157 3-017-0866-4

Adhami S, Giudici G, Martinazzi S (2018) Why do businesses go crypto?: An empirical analysis of initial coin offerings. J Econ Bus 100:64-75. https://doi.org/10.1016/j.jeconbus.2018.04.001

Ahlers GK, Cumming DJ, Günther C, Schweizer D (2015) Signaling in equity crowdfunding. Entrep Theory Pract 39:955-980. https://doi.org/10.1111/etap.12157

Alexy OT, Block JH, Sandner P, Ter Wal ALJ (2012) Social capital of venture capitalists and start-up funding. Small Bus Econ 39:835-851. https://doi.org/10.1007/s11187-011-9337-4

Alvarez-Garrido E, Dushnitsky G (2016) Are entrepreneurial venture's innovation rates sensitive to investor complementary assets?: Comparing biotech ventures backed by corporate and independent VCs. Strateg Manag J 37:819-834. https://doi.org/10.1002/smj.2359

Amornsiripanitch N, Gompers PA, Xuan Y (2015) More than money: venture capitalists on boards. SSRN Electron J. https://doi.org/10.2139/ssrn.2586592

Amsden R, Schweizer D (2018) Are blockchain crowdsales the new "Gold Rush"?: Success determinants of initial coin offerings. SSRN Electron J. https://doi.org/10.2139/ssrn.3163849

An J, Duan T, Hou W, Xu X (2019) Initial coin offerings and entrepreneurial finance: the role of founders' characteristics. J Altern Invest 21:26-40

Ante L, Sandner P, Fiedler I (2018) Blockchain-based ICOs: pure hype or the dawn of a new era of startup financing? J Risk Financ Manag 11:80. https://doi.org/10.3390/jrfm11040080

Ashta A, Biot-Paquerot G (2018) FinTech evolution: strategic value management issues in a fast changing industry. Strateg Change 27:301-311. https://doi.org/10.1002/jsc.2203

Bakos Y, Halaburda H (2018) The role of cryptographic tokens and ICOs in fostering platform adoption. SSRN Electron J. https://doi.org/10.2139/ssrn.3207777

Bartus T (2005) Estimation of marginal effects using margeff. Stata J 5:309-329

Baum JA, Silverman BS (2004) Picking winners or building them?: Alliance, intellectual, and human capital as selection criteria in venture financing and performance of biotechnology startups. J Bus Ventur 19:411-436. https://doi.org/10.1016/S0883-9026(03)00038-7

Benedetti HE, Kostovetsky L (2018) Digital tulips?: Returns to investors in initial coin offerings. SSRN Electron J. https://doi.org/10.2139/ssrn.3182169

Bertoni F, Colombo MG, Grilli L (2011) Venture capital financing and the growth of high-tech start-ups: disentangling treatment from selection effects. Res Policy 40:1028-1043. https://doi.org/10.1016/j. respol.2011.03.008

Bertoni F, Colombo MG, Quas A, Tenca F (2019) The changing patterns of venture capital investments in Europe. J Ind Bus Econ 46:229-250. https://doi.org/10.1007/s40812-019-00113-1

Bertoni F, Tykvová T (2012) Which form of venture capital is most supportive of innovation? http://hdl. handle.net/10419/56030. Accessed 25 Dec 2019

Blaseg D (2018) Dynamics of voluntary disclosure in the unregulated market for initial coin offerings. SSRN Electron J. https://doi.org/10.2139/ssrn.3207641

Block JH, Colombo MG, Cumming DJ, Vismara S (2018) New players in entrepreneurial finance and why they are there. Small Bus Econ 50:239-250. https://doi.org/10.1007/s11187-016-9826-6

Bocks K, Haas C, Heyden T (2019) A theory on pre-ICO venture capital involvement. SSRN Electron J. https://doi.org/10.2139/ssrn.3402623

Boreiko D, Sahdev NK (2018) To ICO or not to ICO-empirical analysis of initial coin offerings and token sales. SSRN Electron J. https://doi.org/10.2139/ssrn.3209180

Boreiko D, Vidusso G (2019) New blockchain intermediaries: do ICO rating websites do their job well? J Altern Invest 21:67-79. https://doi.org/10.3905/jai.2019.21.4.067 
Bottazzi L, Darin M, Hellmann T (2008) Who are the active investors?: Evidence from venture capital. J Financ Econ 89:488-512. https://doi.org/10.1016/j.jfineco.2007.09.003

Breuer W, Pinkwart A (2018) Venture capital and private equity finance as key determinants of economic development. J Bus Econ 88:319-324. https://doi.org/10.1007/s11573-018-0892-X

Catalini C, Gans JS (2018) Initial coin offerings and the value of crypto tokens. SSRN Electron J. https:// doi.org/10.2139/ssrn.3137213

Certo ST, Busenbark JR, Woo H, Semadeni M (2016) Sample selection bias and Heckman models in strategic management research. Strateg Manag J 37:2639-2657. https://doi.org/10.1002/smj.2475

Chanson M, Wortmann F, Risius M (2018) Initial coin offerings (ICOs): an introduction to the novel funding mechanism based on blockchain technology. In: Proceedings of the 24th Americas conference on information systems (AMCIS), New Orleans, LA, USA, 2018

Chatterjee S, Hadi AS (2006) Regression analysis by example. Wiley-Interscience, Hoboken

Chemmanur TJ, Krishnan K, Nandy DK (2011) How does venture capital financing improve efficiency in private firms?: A look beneath the surface. Rev Financ Stud 24:4037-4090. https://doi. org/10.1093/rfs/hhr096

Chemmanur TJ, Loutskina E, Tian X (2014) Corporate venture capital, value creation, and innovation. Rev Financl Stud 27:2434-2473. https://doi.org/10.1093/rfs/hhu033

Chen Y (2018) Blockchain tokens and the potential democratization of entrepreneurship and innovation. Bus Horiz 61:567-575. https://doi.org/10.1016/j.bushor.2018.03.006

Chen Z, Li Y, Wu Y, Luo J (2017) The transition from traditional banking to mobile internet finance: an organizational innovation perspective-a comparative study of Citibank and ICBC. Financ Innov 3:57. https://doi.org/10.1186/s40854-017-0062-0

Chod J, Lyandres E (2018) A theory of ICOs: diversification, agency, and information asymmetry. SSRN Electron J. https://doi.org/10.2139/ssrn.3159528

Chohan UW (2017) Initial coin offerings (ICOs): risks, regulation, and accountability. SSRN Electron J. https://doi.org/10.2139/ssrn.3080098

Colombo MG, Franzoni C, Rossi-Lamastra C (2015) Internal social capital and the attraction of early contributions in crowdfunding. Entrep Theory Pract 39:75-100. https://doi.org/10.1111/etap.12118

Colombo MG, Grilli L (2005) Founders' human capital and the growth of new technology-based firms: a competence-based view. Res Policy 34:795-816. https://doi.org/10.1016/j.respol.2005.03.010

Colombo MG, Grilli L (2010) On growth drivers of high-tech start-ups: exploring the role of founders' human capital and venture capital. J Bus Ventur 25:610-626. https://doi.org/10.1016/j.jbusv ent.2009.01.005

Connelly BL, Certo ST, Ireland RD, Reutzel CR (2010) Signaling theory: a review and assessment. J Manag 37:39-67. https://doi.org/10.1177/0149206310388419

Croce A, Guerini M, Ughetto E (2016) Angel financing and the performance of high-tech start-ups. J Small Bus Manag. https://doi.org/10.1111/jsbm.12250

Cumming DJ, Johan SAB (2007) Advice and monitoring in venture finance. Financ Mark Portf Manag 21:3-43. https://doi.org/10.1007/s11408-006-0041-3

Cumming DJ, Johan SAB (2010) Venture capital investment duration. J Small Bus Manag 2:228-257

Davila A, Foster G, Gupta M (2003) Venture capital financing and the growth of startup firms. J Bus Ventur 18:689-708. https://doi.org/10.1016/S0883-9026(02)00127-1

Dias RdS, Macedo MAdS (2016) Private equity and venture capital funds: what drives the demand and supply? BAR Braz Adm Rev 13:1-21. https://doi.org/10.1590/1807-7692bar2016150058

Dierksmeier C, Seele P (2018) Cryptocurrencies and business ethics. J Bus Ethics 152:1-14. https://doi. org/10.1007/s10551-016-3298-0

Dowlat S (2018) Cryptoasset market coverage initiation: network creation. https://research.bloomberg. com/pub/res/d28giW28tf6G7T_Wr77aU0gDgFQ. Accessed 2 Nov 2020

Dushnitsky G, Lavie D (2010) How alliance formation shapes corporate venture capital investment in the software industry: a resource-based perspective. Strat Entrep J 4:22-48. https://doi.org/10.1002/sej.81

Dusil G, Cerny D (2018) The next evolution in funding innovation. In: 2018 international joint conference on neural networks (IJCNN). IEEE, pp 1-4

Eesley CE, Roberts EB (2012) Are you experienced or are you talented?: When does innate talent versus experience explain entrepreneurial performance? Strat Entrep J 6:207-219. https://doi.org/10.1002/ sej. 1141

Eisenhardt KM, Schoonhoven CB (1990) Organizational growth: linking founding team, strategy, environment, and growth among U.S. semiconductor ventures, 1978-1988. Adm Sci Q 35:504. https:// doi.org/10.2307/2393315 
Ernst, Young (2018) Big risks in ICO market: flawed token valuations, unclear regulations, heightened hacker attention and congested networks. https://www.ey.com/en_kw/news/2018/01/big-risks-inico-market--flawed-token-valuations--unclear-regulations-heightened-hacker-attention-and-conge sted-networks. Accessed 2 Nov 2020

Fisch C (2019) Initial coin offerings (ICOs) to finance new ventures. J Bus Ventur 34:1-22. https://doi. org/10.1016/j.jbusvent.2018.09.007

Fisch C, Momtaz PP (2019) Venture capital and the performance of blockchain technology-based firms: evidence from initial coin offerings (ICOs). SSRN Electron J. https://doi.org/10.2139/ssrn.3427025

Friedlmaier M, Tumasjan A, Welpe I (2018) Disrupting industries with blockchain: the industry, venture capital funding, and regional distribution of blockchain ventures. HICSS

Fromberger M, Haffke L (2019) ICO market report 2018/2019-performance analysis of 2018's initial coin offerings. SSRN Electron J. https://doi.org/10.2139/ssrn.3512125

Galloway TL, Miller DR, Sahaym A, Arthurs JD (2017) Exploring the innovation strategies of young firms: Corporate venture capital and venture capital impact on alliance innovation strategy. J Bus Res 71:55-65. https://doi.org/10.1016/j.jbusres.2016.10.017

Gilbert BA, McDougall PP, Audretsch DB (2008) Clusters, knowledge spillovers and new venture performance: an empirical examination. J Bus Ventur 23:405-422. https://doi.org/10.1016/j.jbusv ent.2007.04.003

Gomber P, Kauffman RJ, Parker C, Weber BW (2018) On the fintech revolution: interpreting the forces of innovation, disruption, and transformation in financial services. J Manag Inf Syst 35:220-265. https://doi.org/10.1080/07421222.2018.1440766

Gomber P, Koch J-A, Siering M (2017) Digital finance and FinTech: current research and future research directions. J Bus Econ 87:537-580. https://doi.org/10.1007/s11573-017-0852-x

Gompers P, Kovner A, Lerner J (2009) Specialization and success: evidence from venture capital. J Econ Manag Strat 18:817-844. https://doi.org/10.1111/j.1530-9134.2009.00230.x

Greene WH (2000) Econometric analysis, 4. ed., internat. ed. Prentice Hall Internat, Upper Saddle River

Grilli L, Murtinu S (2015) New technology-based firms in Europe: market penetration, public venture capital, and timing of investment. Ind Corp Change 24:1109-1148. https://doi.org/10.1093/icc/ dtu025

Gulati R, Higgins MC (2003) Which ties matter when?: The contingent effects of interorganizational partnerships on IPO success. Strateg Manag J 24:127-144. https://doi.org/10.1002/smj.287

Hagendorff J, Bartkus JR, Kabir Hassan M (2009) Specialization versus diversification in venture capital investing. J Financ Regul Compliance 17:134-145. https://doi.org/10.1108/13581980910952577

Hamza O, Kooli M (2011) Does venture capitalists reputation improve the survival profile of IPO firms? SSRN Electron J. https://doi.org/10.2139/ssrn.1857012

Heckman JJ (1976) The common structure of statistical models of truncation, sample selection and limited dependent variables and a simple estimator for such models. Ann Econ Soc Meas 5:475-492

Heckman JJ (1979) Sample selection bias as a specification error. Econometrica 47:153. https://doi. org/10.2307/1912352

Hellmann T (2002) A theory of strategic venture investing. J Financ Econ 64:285-314. https://doi. org/10.1016/S0304-405X(02)00078-8

Hellmann T, Puri M (2002) Venture capital and the professionalization of start-up firms: empirical evidence. J Finance 57:169-197

Hochberg YV, Mazzeo MJ, McDevitt RC (2015) Specialization and Competition in the Venture Capital Industry. Rev Ind Organ 46:323-347. https://doi.org/10.1007/s11151-015-9462-3

Hoenig D, Henkel J (2015) Quality signals?: The role of patents, alliances, and team experience in venture capital financing. Res Policy 44:1049-1064. https://doi.org/10.1016/j.respol.2014.11.011

Homburg C, Hahn A, Bornemann T, Sandner P (2013) The role of chief marketing officers for venture capital funding: endowing new ventures with marketing legitimacy. J Mark Res 51:625-644. https ://doi.org/10.1509/jmr.11.0350

Hornuf L, Kück T, Schwienbacher A (2019) Initial coin offerings, information disclosure, and fraud. CESifo Working Paper Series 7962, CESifo

Howell S, Niessner M, Yermack D (2018) Initial coin offerings: financing growth with cryptocurrency token sales. SSRN Electron J. https://doi.org/10.2139/ssrn.3201259

Howell ST, Niessner M, Yermack D (2020) Initial coin offerings: financing growth with cryptocurrency token sales. Rev Financ Stud 33:3925-3974. https://doi.org/10.1093/rfs/hhz131

Hsu DH (2004) What do entrepreneurs pay for venture capital affiliation? J Finance 59:1805-1844. https ://doi.org/10.1111/j.1540-6261.2004.00680.x 
Huang W, Meoli M, Vismara S (2019) The geography of initial coin offerings. Small Bus Econ 40:7. https://doi.org/10.1007/s11187-019-00135-y

Ivanov VI, Xie F (2010) Do Corporate venture capitalists add value to start-up firms?: Evidence from IPOs and acquisitions of VC-backed companies. Financ Manag 39:129-152. https://doi. org/10.1111/j.1755-053X.2009.01068.x

Jackson WE, Bates T, Bradford WD (2012) Does venture capitalist activism improve investment performance? J Bus Ventur 27:342-354. https://doi.org/10.1016/j.jbusvent.2011.02.003

KPMG (2019) Venture pulse Q2 2019: global analysis of venture funding. https://assets.kpmg/content/ dam/kpmg/xx/pdf/2019/07/venture-pulse-q2-2019-global.pdf. Accessed 27 Dec 2019

Kaal WA, Dell'Erba M (2017) Initial coin offerings: emerging practices, risk factors, and red flags. SSRN Electron J. https://doi.org/10.2139/ssrn.3067615

Kaplan SN, Lerner J (2010) It Ain't broke: the past, present, and future of venture capital. J Appl Corp Finance 22:36-47. https://doi.org/10.1111/j.1745-6622.2010.00272.x

Kaplan SN, Lerner J (2016) Venture capital data: opportunities and challenges. https://doi.org/10.3386/ w22500

Kastelein R (2017) What Initial Coin Offerings Are, and Why VC Firms Care. https://hbr.org/2017/03/ what-initial-coin-offerings-are-and-why-vc-firms-care. Accessed 20 Dec 2019

Kenney M, Zysman J (2019) The platform economy and geography: restructuring the space of capitalist accumulation. SSRN Electron J. https://doi.org/10.2139/ssrn.3497978

Kharif O, Russo C (2018) Venture capital surges into crypto startups. https://www.bloomberg.com/news/ articles/2018-03-26/icos-can-wait-venture-capital-surges-into-crypto-startups. Accessed 20 Dec 2019

Kim S, Sarin A (2018) Distributed ledger and blockchain technology: framework and use cases. SSRN Electron J. https://doi.org/10.2139/ssrn.3373347

Kranz J, Nagel E, Yoo Y (2019) Blockchain token sale. Bus Inf Syst Eng 24:3. https://doi.org/10.1007/ s12599-019-00598-Z

Krishnan CNV, Ivanov VI, Masulis RW, Singh AK (2011) Venture capital reputation, post-IPO performance, and corporate governance. J Financ Quant Anal 46:1295-1333. https://doi.org/10.1017/ S0022109011000251

Lavie D (2006) The competitive advantage of interconnected firms: an extension of the resource-based view. Acad Manag Rev 31:638-658

Lee PM, Pollock TG, Jin K (2011) The contingent value of venture capitalist reputation. Strateg Organ 9:33-69. https://doi.org/10.1177/1476127011400505

Li J, Mann W (2018) Initial coin offering and platform building. SSRN Electron J. https://doi. org/10.2139/ssrn.3088726

Liebau D, Scheuffel P (2019) Cryptocurrencies \& initial coin offerings: are they scams? - An empirical study. J Br Blockchain Assoc 2:1-7. https://doi.org/10.31585/jbba-2-1-(5)2019

Lin L, Nestarcova D (2019) Venture capital in the rise of crypto economy: problems and prospects. NUS Law Working Paper No. 2019/003. Berkeley Business Law Journal 16

Lindsey L (2002) The venture capital keiretsu effect: an empirical analysis of strategic alliances among portfolio firms. SIEPR Discussion Paper No. 02-17, Stanford University

Long SJ (1997) Regression models for categorical and limited dependent variables. Sage, Thousand Oaks (Calif.)

Lyandres E, Palazzo B, Rabetti D (2018) Are tokens securities? An anatomy of initial coin offerings. Working Paper

Malinova K, Park A (2018) Tokenomics: When tokens beat equity (November 18, 2018). Available at SSRN: https://ssrn.com/abstract=3286825 or https://doi.org/10.2139/ssrn.3286825

Matusik SF, Fitza MA (2012) Diversification in the venture capital industry: leveraging knowledge under uncertainty. Strateg Manag J 33:407-426. https://doi.org/10.1002/smj.1942

Megginson WL, Weiss KA (1991) Venture capitalist certification in initial public offerings. J Finance 46:879-903. https://doi.org/10.1111/j.1540-6261.1991.tb03770.x

Mollick E (2014) The dynamics of crowdfunding: an exploratory study. J Bus Ventur 29:1-16. https:// doi.org/10.1016/j.jbusvent.2013.06.005

Momtaz PP (2018) CEO loyalty and the pricing of initial coin offerings. SSRN Electron J. https://doi. org/10.2139/ssrn.3167061

Momtaz PP (2019) Token sales and initial coin offerings: introduction. J Altern Invest 21:7-12. https:// doi.org/10.3905/jai.2019.21.4.007 
Momtaz PP (2020) Entrepreneurial finance and moral hazard: evidence from token offerings. J Bus Ventur. https://doi.org/10.1016/j.jbusvent.2020.106001

Le Nadant A-L, Perdreau F, Bruining H (2018) Industry specialization of private equity firms: a source of buy-out performance heterogeneity. Venture Cap 20:237-259. https://doi.org/10.1080/13691 066.2017 .1422424

Nahata R (2008) Venture capital reputation and investment performance. J Financ Econ 90:127-151

Nakamoto S (2008) Bitcoin: a peer-to-peer electronic cash system. Available at https://bitcoin.org/bitco in.pdf

Nanda R, Rhodes-Kropf M (2013) Investment cycles and startup innovation. J Financ Econ 110:403-418. https://doi.org/10.1016/j.jfineco.2013.07.001

Novak M (2019) Crypto-friendliness: understanding blockchain public policy. J Entrep Public Policy 9:165-184

O'brien RM (2007) A caution regarding rules of thumb for variance inflation factors. Qual Quant 41:673-690. https://doi.org/10.1007/s11135-006-9018-6

Paik Y, Woo H (2017) The Effects of corporate venture capital, founder incumbency, and their interaction on entrepreneurial firms' R\&D investment strategies. Organ Sci 28:670-689. https://doi. org/10.1287/orsc.2017.1133

Park HD, Steensma HK (2012) When does corporate venture capital add value for new ventures? Strateg Manag J 33:1-22. https://doi.org/10.1002/smj.937

Peteraf MA (1993) The cornerstones of competitive advantage a resource based view. Strateg Manag J 14:179-191

Phalippou L (2010) Venture capital funds: flow-performance relationship and performance persistence. J Bank Finance 34:568-577. https://doi.org/10.1016/j.jbankfin.2009.08.022

Puri M, Zarutskie R (2012) On the life cycle dynamics of venture-capital- and non-venture-capitalfinanced firms. J Finance 67:2247-2293. https://doi.org/10.1111/j.1540-6261.2012.01786.x

Rajan R, Servaes H, Zingales L (2000) The cost of diversity: the diversification discount and inefficient investment. J Finance 55:35-80. https://doi.org/10.1111/0022-1082.00200

Rhue L (2018) Trust is all you need: an empirical exploration of initial coin offerings (ICOs) and ICO reputation scores. SSRN Electron J. https://doi.org/10.2139/ssrn.3179723

Rindova VP, Williamson IO, Petkova AP (2005) Being good or being known: an empirical examination of the dimensions, antecedents, and consequences of organizational reputation. Acad Manag J 48:1033-1049

Rosenbusch N, Brinckmann J, Müller V (2013) Does acquiring venture capital pay off for the funded firms?: A meta-analysis on the relationship between venture capital investment and funded firm financial performance. J Bus Ventur 28:335-353. https://doi.org/10.1016/j.jbusvent.2012.04.002

Rossi M, Festa G, Solima L, Popa S (2017) Financing knowledge-intensive enterprises: evidence from CVCs in the US. J Technol Transf 42:338-353. https://doi.org/10.1007/s10961-016-9495-2

Russell J (2018) The rollercoaster-get-rich ICO. https://techcrunch.com/2018/09/12/icos-are-increasing ly-just-for-venture-capitalists. Accessed 20 Dec 2019

Sameeh T (2018) ICO basics-the difference between security tokens and utility tokens. https://www. cointelligence.com/content/ico-basics-security-tokens-vs-utility-tokens/. Accessed 20 Dec 2019

Sandner P, Block JH, Lutz A (2008) Determinanten des Erfolgs staatlich geförderter Existenzgründungen-eine empirische Untersuchung. Z Betriebswirtsch 78:753-777

Sapienza HJ (1992) When do venture capitalists add value? J Bus Ventur 7:9-27. https://doi. org/10.1016/0883-9026(92)90032-M

Sapienza HJ, Manigart S, Vermeir W (1996) Venture capitalist governance and value added in four countries. J Bus Ventur 11:439-469. https://doi.org/10.1016/S0883-9026(96)00052-3

Sartori AE (2003) An estimator for some binary-outcome selection models without exclusion restrictions. Political Anal 11:111-138. https://doi.org/10.1093/pan/mpg001

Scharfstein DS, Stein JC (2000) The dark side of internal capital markets: divisional rent-seeking and inefficient investment. J Finance 55:2537-2564. https://doi.org/10.1111/0022-1082.00299

Schlichte F, Junge S, Mammen J (2019) Being at the right place at the right time: Does the timing within technology waves determine new venture success? J Bus Econ 31:305. https://doi.org/10.1007/ s11573-019-00947-0

Shapiro C (1983) Premiums for high quality products as returns to reputations. Q J Econ 98:659-679. https://doi.org/10.2307/1881782 
Shifflett S, Jones C (2018) Buyer Beware: hundreds of Bitcoin Wannabes Show Hallmarks of Fraud. https ://www.wsj.com/articles/buyer-beware-hundreds-of-bitcoin-wannabes-show-hallmarks-of-fraud -1526573115. Accessed 2 Nov 2020

Shu P-G, Yeh Y-H, Chiu S-B, Ho F-S (2011) The reputation effect of venture capital. Rev Quant Financ Acc 36:533-554. https://doi.org/10.1007/s11156-010-0188-x

Siddiqui A, Marinova D, Hossain A (2016) Venture capital firms' specialization, differences and complementarities. Int J Bus Manag 11:83. https://doi.org/10.5539/ijbm.v11n7p83

Spence M (1973) Job market signaling. Q J Econ 87:355-374

Streletzki J-G, Schulte R (2013) Which venture capital selection criteria distinguish high-flyer investments? Venture Cap 15:29-52. https://doi.org/10.1080/13691066.2012.724232

Stuart TE, Hoang H, Hybels RC (1999) Interorganizational endorsements and the performance of entrepreneurial ventures. Adm Sci Q 44:315. https://doi.org/10.2307/2666998

Stuart T, Sorenson O (2003) The geography of opportunity: spatial heterogeneity in founding rates and the performance of biotechnology firms. Res Policy 32:229-253. https://doi.org/10.1016/S0048 $-7333(02) 00098-7$

Sultan K, Ruhi U, Lakhani R (2018) Proceedings of the 11th IADIS international conference on information systems 2018. In: Proceedings of the 11th IADIS international conference on information systems 2018, pp 49-57

Tiwari M, Gepp A, Kumar K (2020) The future of raising finance-a new opportunity to commit fraud: a review of initial coin offering (ICOs) scams. Crime Law Soc Change 73:417-441. https://doi. org/10.1007/s10611-019-09873-2

Tucker JW (2010) Selection bias and econometric remedies in accounting and finance research. J Acc Lit 29:31-57

Tykvová T (2018) Venture capital and private equity financing: an overview of recent literature and an agenda for future research. J Bus Econ 88:325-362. https://doi.org/10.1007/s11573-017-0874-4

Varma JR (2019) Blockchain in finance. Vikalpa J Decis Mak 44:1-11. https://doi.org/10.1177/02560 90919839897

Vella F, Verbeek M (1999) Estimating and interpreting models with endogenous treatment effects. J Bus Econ Stat 17:473-478

van de Ven WP, van Praag BM (1981) The demand for deductibles in private health insurance. J Econ 17:229-252. https://doi.org/10.1016/0304-4076(81)90028-2

Verbeek M (2004) A guide to modern econometrics, 2. ed., reprint. with corr. Wiley, Chichester

Vismara S (2015) Information cascades among investors in equity crowdfunding. Acad Manag Proc 2015:11519. https://doi.org/10.5465/ambpp.2015.11519abstract

Vismara S (2016) Equity retention and social network theory in equity crowdfunding. Small Bus Econ 46:579-590. https://doi.org/10.1007/s11187-016-9710-4

Werth JC, Boeert P (2013) Co-investment networks of business angels and the performance of their startup investments. Int J Entrep Ventur. https://doi.org/10.1504/IJEV.2013.055292

Winston Smith S, Robb AM (2011) Who seeks and who receives? Implications of demand for and access to financial capital by young firms. Edited by Kauffman Foundation. Kansas City

Wolfolds SE, Siegel J (2019) Misaccounting for endogeneity: the peril of relying on the Heckman twostep method without a valid instrument. Strateg Manag J 40:432-462. https://doi.org/10.1002/ smj.2995

World Economic Forum (2016) Top 10 emerging technologies of 2016. https://www.weforum.org/agend a/2016/06/top-10-emergingtechnologies-2016/

Xu M, Chen X, Kou G (2019) A systematic review of blockchain. Financ Innov 5:64. https://doi. org/10.1186/s40854-019-0147-z

Zacharakis AL, McMullen JS, Shepherd DA (2007) Venture capitalists' decision policies across three countries: an institutional theory perspective. J Int Bus Stud 38:691-708. https://doi.org/10.1057/ palgrave.jibs.8400291

Zaheer S (1995) Overcoming the liability of foreignness. Acad Manag J 38:341-363. https://doi. org/10.5465/256683

Zetzsche DA, Buckley RP, Arner DW, Ffhr L (2017) The ICO gold rush: it's a scam, it's a bubble, it's a super challenge for regulators. SSRN Electron J. https://doi.org/10.2139/ssrn.3072298

Publisher's Note Springer Nature remains neutral with regard to jurisdictional claims in published maps and institutional affiliations. 